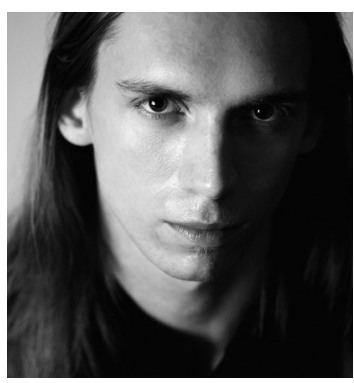

Krzysztof Grudnik

Krzysztof Grudnik - doktorant w Zakładzie Literatury Poromantycznej Uniwersytetu Śląskiego, laureat XV edycji konkursu im. J. J. Lipskiego, tłumacz i krytyk literacki. Publikował m.in. w tomach: Czytanie Różewicza (2010), Czytanie Śląska i Zagłębia (2009), Bogactwo polszczyzny w świetle jej historii (t. 3, 2010) oraz na łamach "artPapieru" i miesięcznika "Akant". Zajmuje się literatura „niesamowita”, wpływem ruchów okultystycznych na literaturę przełomu XIX i XX wieku oraz literackimi obliczami kontrkultury. 


\section{Tożsamość katoptryczna w nowelistyce Stefana Grabińskiego}

twórczości Stefana Grabińskiego trzy tematy znalazły szczególnie szeroką realizację: genius loci, kobieta i sobowtór. Pierwsze dwa doczekały się już opracowań. Tematykę genius loci podejmuje Dagmara Zając ${ }^{1}$, kobiece kreacje zostały opracowane przez Krystynę Kłosińską, Barbarę Zwolińską oraz Martę Kikę-Koj². Natomiast zagadnienie sobowtóryzmu nie było dotąd, stosownie do swej wagi, omówione ${ }^{3}$.

Jedynie Artur Hutnikiewicz w swej monografii poświęconej twórczości literackiej autora Salamandry stara się nakreślić ten temat nieco wyraźniej (TLSG, s. 221-224), jednakże jest to wąski fragment obszernej problematyki poruszanej w książce, więc z konieczności potraktowany został powierzchownie. Ponadto istnieją dwie zasadnicze różnice pomiędzy perspektywą badawczą przyjętą przez Hutnikiewicza a moją.

Pierwsza dotyczy psychologicznego ujmowania zagadnień. Pisząc swe dzieło pół wieku temu, Hutnikiewicz powołuje się na badania Ribota czy Charcota, kończąc (chronologicznie) na Freudzie. Ja klasyków psychologii i psychopatologii traktuję tylko jako kontekst kulturowy. $\mathrm{Z}$ metodologicznego punktu widzenia Freud jest dla mnie raczej początkiem niż końcem. Interesuje mnie bardziej odczytanie nowel Grabińskiego przez pryzmat dzisiejszej psychoanalizy - od Freuda, przez Junga, kończąc na Lacanie i Žižku, których koncepcjom poświęcam dużo uwagi.

1 D. Zając, Droga a polimorfizm bytu w nowelistyce Stefana Grabińskiego, "Kwartalnik Opolski” 2003, nr 1. O zastosowaniu kategorii genius loci we współczesnej teorii kultury i literatury zob. Genius loci. Studia o człowieku w przestrzeni, red. Z. Kadłubek, Katowice 2007.

2 K. Kłosińska, Fantazmaty. Grabiński - Prus - Zapolska, Katowice 2004; B. Zwolińska, Wampiryzm w literaturze romantycznej i postromantycznej na przykładzie "Opowieści niesamowitych" Edgara Allana Poego „Poganki” Narcyzy Żmichowskiej oraz opowiadań Stefana Grabińskiego, Gdańsk 2002; M. Kika-Koj, Demoniczne kobiety Stefana Grabińskiego, „Fa-Art” 1996, nr 4. Przy czym Kłosińska skupia się na Kochance Szamoty, a Zwolińska głównie na W domu Sary. Istnieje także popularne ujęcie tego tematu: A. Haska, J. Stachowicz, Patrzyła na niego pochutliwie, "Nowa Fantastyka” 2005, nr 10.

${ }^{3}$ B. Zwolińska, op. cit., s. 21; M. Podraza-Kwiatkowska, Młodopolskie konstrukcje sobowtórowe, [w:] eadem, Somnambulicy, dekadenci, herosi. Studia i eseje o literaturze Młodej Polski, Kraków 1985, s. 114; D. Zając, op. cit., s. 55. 


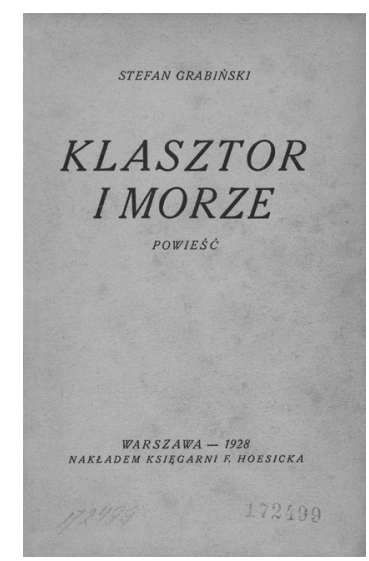

S. Grabiński, Klasztor i morze. Powieść, Księgarnia F. Hoesicka, Warszawa 1928
Druga różnica polega na odmiennym rozumieniu fantastyczności w nowelach Grabińskiego. Wydaje się, że dla Hutnikiewicza utwory te są w gruncie rzeczy realistyczne, miejscami tylko zawierają elementy fantastyczne, które i tak można wytłumaczyć naukowo. Dla mnie inaczej - twórczość Grabińskiego to nie fantastyczne elementy przedzierające się do realistycznego świata, lecz realistyczne elementy obecne w zupełnie fantastycznym świecie.

Przyjrzenie się małym formom prozatorskim tego autora przez pryzmat zjawiska sobowtóryzmu odkrywa mnogość jego ujęć i realizacji. Ponieważ często odbiegają one od popularnych konotacji określenia „sobowtór”, podjąłem próbę wprowadzenia terminu tożsamości katoptrycznej, czyli tożsamości odbitej i jednocześnie rozbitej, zwielokrotnionej. Rozmaite jej aspekty oraz powiązane z nią zagadnienia stanowią oś moich rozważań.

Gabriela Matuszek tak pisała o chorobach psychicznych młodopolskich artystów:

W każdej epoce inne zjawiska patologiczne zajmują pozycję dominującą, można by rzec, iż specyfika owych zaburzeń odsłania jej podziemne wiry i prądy. Twórca to nie tylko medium własnej podświadomości - co odkryto, choć nie do końca zwerbalizowano już na przełomie XIX i XX wieku - jego psychika i wydane przez nią dzieło znajdują się w realnej przyległości do sfery nieświadomości zbiorowej kulturowego otoczenia ${ }^{4}$.

Przekonany o słuszności tego twierdzenia myślę, że w wypadku literatury grozy, zwłaszcza w jej psychologizującym nurcie, znajduje ono szczególne zastosowanie. Utwory takie są zapisem nie tylko prywatnych lęków autora, ale i odzwierciedleniem powszechnych, choć często skrytych obaw całej epoki.

Tożsamość katoptryczna, która w pewien sposób jest antytożsamością, stawia w stan zagrożenia podmiotowość i osobowość. Zjawisko to zarysowało się wyraźnie na początku XX wieku i pozostaje równie ważne i aktualne sto lat później.

\section{Wsobowtóry}

Katoptryka to dziedzina optyki, skupiająca się na szeregu zjawisk fizycznych związanych ze zwierciadłami oraz odbijanymi przez nie obrazami. Twórcą tej nauki był Eurypides, który napisał dwa traktaty: Optyka i Katoptryka, oraz Heron z Aleksandrii, autor Katoptryki. W niniejszej pracy brak jednak bezpośrednich odwołań do fizyki. Włączenie katoptryki w obręb dyskursu humanistycznego w Polsce to zasługa krakowskiego religioznawcy Tomasza Sikory, który w 2004 roku opublikował pracę pod tytułem Euoi. Studia z symbolizmu i metaforyzacji katoptrycznej. W książce autor gromadzi i analizuje obszerny materiał mitograficzny, przedstawiając szeroką paletę funkcji, jakie w różnych kulturach pełni lustro, oraz ogrom znaczeń związanych z wszelkiego rodzaju odbiciami.

Terminem „tożsamość katoptryczna” pragnę ogarnąć szereg zjawisk, których pojęcie tożsamości odbitej nie konotuje bądź czyni to zbyt słabo. Katoptryczność w sferze tożsamości objawiać się może w motywie bliźniaków, w sytuacjach sobowtórowych, w relacjach rodzic-dziecko, w wypadkach rozszczepienia jaźni, w zjawiskach wypierania jednej tożsa-

${ }^{4}$ G. Matuszek, Neuroza, histeria, narcyzm. O wiwisekcjach artysty młodopolskiego, [w:] Z problemów prozy. Powieść o artyście, red. W. Gutowski, E. Owczarz, Toruń 2006, s. 197. 
mości przez drugą, w procesie żałobnej identyfikacji, w wyniku klonowania, w odbiciach lustrzanych (także zniekształconych), również na powierzchni wody, przy reinkarnacji, w stanach hipnotycznych, somnambulicznych, narkotycznych, w postaci sumienia, jako dusza, w obszarze zagadnień dotyczących spirytyzmu, spirytualizmu, ciał astralnych itp., w relacji między twórcą a dziełem.

Lista ta z całą pewnością nie jest zamknięta, zawiera tylko najpopularniejsze przejawy tożsamości katoptrycznej w literaturze. Każdy ze sposobów przejawiania się tej specyficznej konstrukcji jest wewnętrznie złożony. Freud, pisząc o sobowtórach, precyzował:

Chodzi tu o motyw sobowtórstwa we wszystkich jego stopniach i formach, a więc o występowanie osób, które trzeba uważać za identyczne ze względu na identyczny wygląd, o intensyfikowanie tego stosunku za sprawą przeskakiwania procesów psychicznych od jednej osoby do drugiej - co określilibyśmy mianem telepatii - tak że jedna ma udział w wiedzy, czuciu i przeżywaniu drugiej, o utożsamienie jednej osoby z drugą, tak że błądzimy w kwestii ich „ja” lub przenosimy obce ,ja” na miejsce własnego, a zatem chodzi tu o podwojenie "ja”, o podzial "ja", o zamianę „ja” - i w końcu o stały powrót tego samego, o powtarzanie w kolejnych generacjach tych samych rysów twarzy, charakterów, losów, czynów przestępczych, ba, nawet imion ${ }^{5}$.

Wypowiedź psychoanalityka nie tylko uświadamia, jak rozmaicie ujmowany może być każdy przejaw tożsamości katoptrycznej, ale także jak różne przejawy łączą się ze sobą, przeplatają i nakładają. W takiej sytuacji ustalenie kategorii nadrzędnej wydaje się korzystne, umożliwia wskazanie pewnych struktur w obrębie literatury, których poszczególne realizacje mogą na pierwszy rzut oka wydawać się zupełnie od siebie różne.

Tożsamość katoptryczna jest z punktu widzenia podmiotu nieznośna. Przyczyn owego dyskomfortu może być wiele: strach przed konfrontacją z samym sobą, utrata jednostkowości i indywidualności, poczucie moralnej odpowiedzialności za poczynania „drugiego ja” przy jednoczesnym braku kontroli nad nim, ryzyko zamiany, podstawienia sobowtóra w miejsce podmiotu. Są to jednak przejawy lęków o wiele głębszych, dotyczących takich kwestii jak sam status podmiotowości. Konfrontacja $\mathrm{z}$ własnym odbiciem rozbija spójność tożsamości i „odkleja ją” od podmiotu, tak jakby była ona zaledwie maską nałożoną na prawdziwą twarz. Oczywiście odkrycie tego, że warstwa, którą dotychczas uważałem za mnie, okazuje się powłoką (jedną z wielu możliwych) i nie jest mną - ma charakter traumatyczny.

Dlatego kolejnym elementem typowym dla tożsamości katoptrycznej będzie dążenie do reintegracji. Ponowne połączenie się z odbiciem ma zapewnić jedność i spójność Ja. Do integracji dojść może w różny sposób, choć najczęściej opiera się ona na zabiciu (bądź też symbolicznym uśmierceniu) zwielokrotnienia. W takiej sytuacji nie mamy do czynienia ze zwykłym zubożeniem tożsamości poprzez wyeliminowanie alternacji, lecz z wchłonięciem, uwewnętrznieniem odbicia, na skutek czego formuje się zupełnie nowa jakościowo, bogatsza tożsamość. Reintegracja może odbyć się też poprzez uświadomienie sobie jedności z odbiciem, co wcale nie musi być przyjemne, jeśli dokonuje ono czynów odrzucanych przez pierwotną tożsamość. Ale efektem w tym wypadku jest również powstanie nowej tożsamości, wzbogaconej o większą samoświadomość. Należy podkreślić, że o ile d ą ż e n i e do reintegracji jest cechą typową dla tożsamości katoptrycznej, o tyle nie jest ono równo-

${ }^{5}$ S. Freud, Niesamowite, [w:] idem, Pisma psychologiczne, tłum. R. Reszke, Warszawa 1997, s. 247.

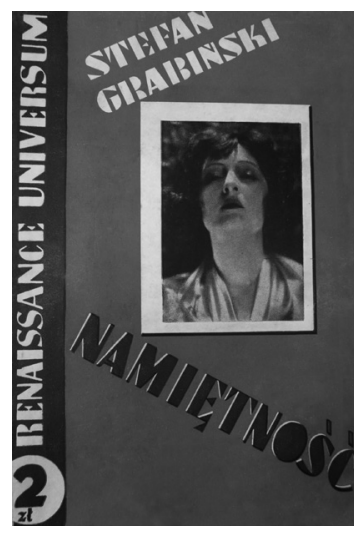

\section{S. Grabiński, Namiętność (L'Appassionata). Opowieść wenecka,} Renaissance-Universum, Warszawa [i in.1930] 
znaczne z o s i ą g n i ę c i e m tego stanu. Możliwy jest brak połączenia z odbiciem lub połączenie poprzez śmierć nie tyle odbicia, co podmiotu (casus Narcyza).

Podstawowe cechy tożsamości katoptrycznej wyglądałyby więc następująco: 1) jedna (lub co najmniej jedna) z form przejawiania się podwojenia w danej sytuacji, relacji itp.; 2) stan zagrożenia podmiotu; 3) dążenie do reintegracji; 4a) wytworzenie się tożsamości jakościowo różnej od tożsamości sprzed rozdwojenia lub $4 \mathrm{~b}$ ) śmierć. Przy czym punkt $4 \mathrm{~b}$ w zasadzie wpisuje się w punkt 4a, jeśli tylko śmierć uznać za stan różny od każdej tożsamości wyjściowej. Zarazem objawia się tu podwójna możliwość rozwiązania sytuacji katoptrycznej: pozytywna (wytworzenie nowej, bogatszej tożsamości) i negatywna (śmierć).

Czy w wypadku tożsamości katoptrycznej można mówić o realnym zwielokrotnieniu, czy też całość traktować należy jedynie i zawsze jako ułudę: zwidy, omamy, projekcje bohaterów? Rozstrzygając tę kwestię, trzeba pamiętać przede wszystkim o materiale, na jakim się pracuje. Otóż mówiąc o tożsamości katoptrycznej, mam zawsze na myśli pewien konstrukt literacki, poruszam się $w$ obszarze literatury. Jest ona zamej swej natury fikcyjna, dlatego trudno mówić o realnym zwielokrotnieniu. Oczywiście prawdziwość może być weryfikowalna do pewnego stopnia wewnątrz samego tekstu, w odniesieniu do świata przedstawionego, jednak będzie to zwykle wynik interpretacji. Możemy uznać istnienie Stachura i profesora Czelawy z opowiadania Problemat Czelawy, a walkę między nimi odczytywać jako starcie dwóch różnych bohaterów. Możemy także nowelę potraktować jako metaforę wewnętrznych zmagań różnych sił tkwiących w człowieku. Nie ukrywam, że to drugie odczytanie jest mi bliższe, jednakże w obu wypadkach zaobserwować będziemy mogli rozwój zdwojonej, odbitej, powtórzonej tożsamości. Théodule-Armand Ribot pisal:

Z fenomenem sobowtóra w „klasycznym” ujęciu spotkać się można najczęściej w okresach przejściowych między dwoma odmiennymi stanami osobowości, gdy formuje się już nowy stan jaźni, a jednocześnie trwa jeszcze stary. W tym okresie wzajemnej osmozy i przenikania pojawia się zazwyczaj najsilniej poczucie dualizmu osobowoścíi

Słowa te pojawily się w polskim wydaniu Chorób osobowości z 1895 roku i dotyczyły chorobowego rozszczepienia jaźni. Ale rok wydania otwiera możliwość pewnej gry z przytoczonym fragmentem. Bo jeśli „stan osobowości” zamienimy na „charakter epoki” (czyli pewien stan osobowości zbiorowej), to otrzymamy doskonały opis sytuacji przełomu XIX i XX wieku: był to moment intensywnego przenikania się i narodzin różnorodnych prądów myślowych. Zaczynały się kształtować nowe zapatrywania na rzeczywistość, podczas gdy stare wciąż były silne i nadal wiodące. Realizm ścierał się z metafizyką, indywidualizm - z masa$\mathrm{mi}$, wolna wola $-\mathrm{z}$ determinizmem. To rzeczywiście mogło wywoływać poczucie rozdarcia czy raczej rozdwojenia. Nie dziwi więc, że stało się ono kolejno: obiektem zainteresowania nauki oraz często wykorzystywanym motywem literackim.

Rozwój psychologii szedł w parze z jej popularyzacją. Prace uczonych nie pozostawały tylko w obiegu naukowym, lecz trafiały także na grunt literacki (TLSG, s. 19-20). Zorientowanie w nowych pracach z zakresu ludzkiej psychiki było elementem towarzyskiej ogła-

${ }^{6}$ T.-A. Ribot, Choroby osobowości, tłum. J. K. Potocki, Warszawa 1895, s. 119. 

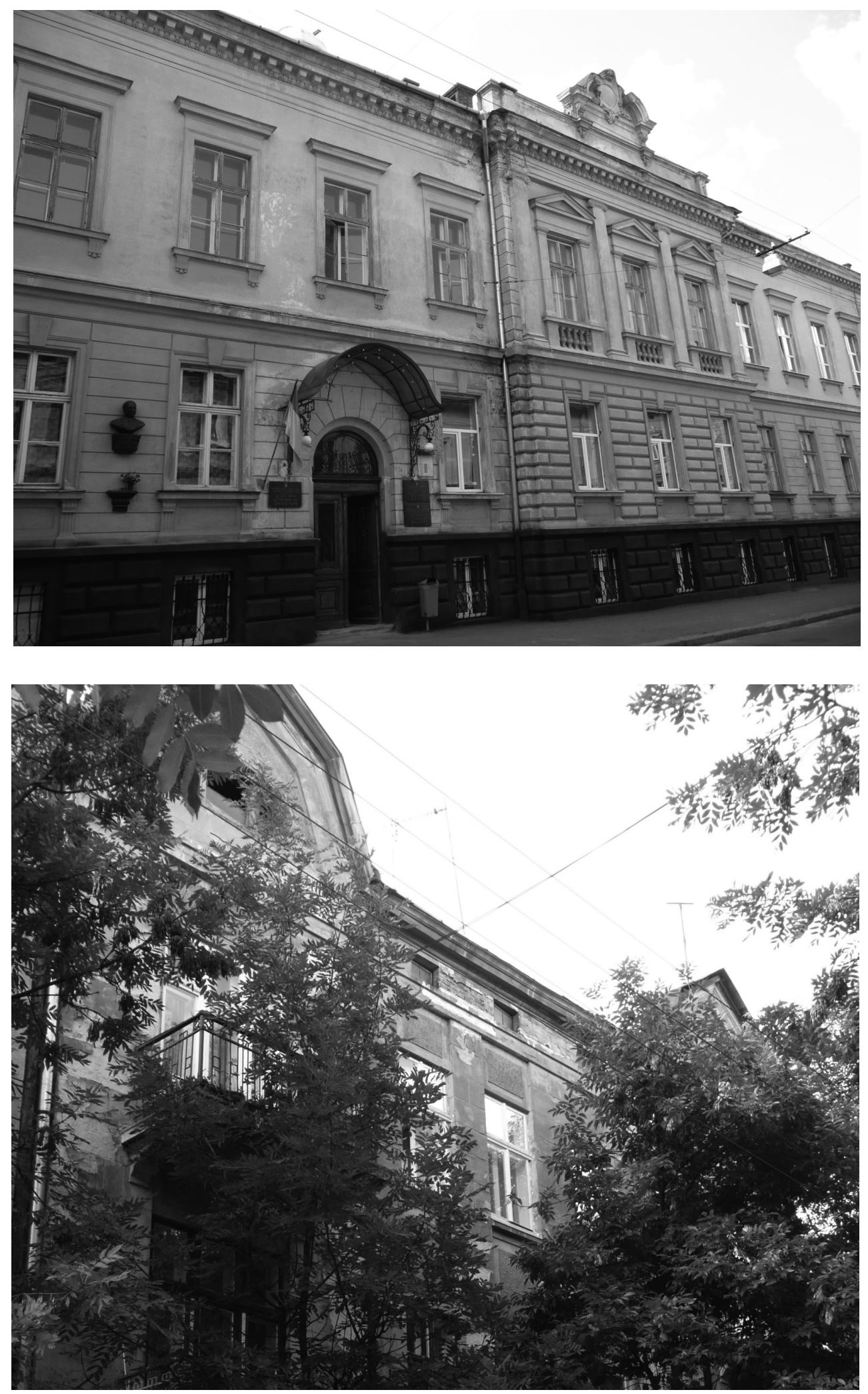

Dawna ul. Długosza 8 we Lwowie, miejsce zamieszkania Grabińskiego w okresie studiów.

Fot. Tomasz Pudłocki, $2010 \mathrm{r}$.
Dawna ul. Murarska 22 we Lwowie, miejsce zamieszkania Grabińskiego w I. 1921-1930.

Fot. Tomasz Pudłocki, $2010 \mathrm{r}$. 


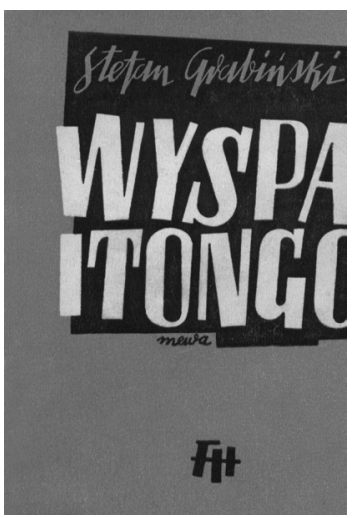

S. Grabiński, Wyspa Itongo. Powieść, Księgarnia F. Hoesicka, Warszawa 1936 $\mathrm{dy}^{7}$. W 1911 roku Ludwik Jekels przełożył na język polski O psychoanalizie Freuda, przez co wpływ tej dziedziny na literaturę polską znacznie się powiększył'

Obecność wspomnianych powyżej zainteresowań w twórczości Stefana Grabińskiego stanowi przesłankę, by dorobek tego pisarza, publikującego głównie w latach 20., zaliczyć do formacji Młodej Polski. Zwrócił na to uwagę Karol Irzykowski, który zaraz po zgonie swego przyjaciela pisał, że „Grabiński należał do ostatniej generacji Młodej Polski, tej, która jeszcze przed wojną otrzymywała swe rozstrzygające wrażenia światopoglądowe i twórcze"9. Twórcy Pałuby po latach wtórował Hutnikiewicz:

Grabiński-pisarz odbierał pierwsze i rozstrzygające impulsy twórcze w tym okresie, gdy silne były jeszcze i żywotne tradycje modernizmu, ekspresjonizm doprowadzał pewne tendencje neoromantyki do ostatecznych konsekwencji, a intuicjonizm Bergsona i psychoanaliza Freuda stając się elementem czasów i wyznaniem wiary intelektualnej elity europejskiej rehabilitowały metafizykę, odkrywały tajemnicze, niepokojące głębie podświadomości [TLSG, s. 118].

O ile pierwsza część tego zdania brzmi nieomal jak przytoczenie wypowiedzi Irzykowskiego, o tyle dalsza część wprowadza typową dla Hutnikiewicza tendencję do racjonalizowania metafizyki. Łączy on fantastyczność z psychologią, podkreśla reinterpretację pierwszej poprzez pryzmat drugiej:

Gdy w romantyzmie cudowność i irracjonalizm były na ogół tylko formą marzenia, dekoracją, ozdobą, igraszką rozbawionej wyobraźni lub co najwyżej symbolem czy alegorią, fantastyka modernizmu zdołała już wchłonąć i zasymilować wszystkie niemal zdobycze nowoczesnej nauki, psychiatrii i psychopatologii, wszystkie doświadczenia mediumizmu i spirytyzmu, starej i nowej „wiedzy tajemnej” [TLSG, s. 43-44].

Racjonalizowanie elementów fantastycznych może być krzywdzące dla literatury, która na nich się opiera. Odarcie nowel Grabińskiego z niezwykłości, z kluczowej dla nich niesamowitości, wydaje się zubażać dzieło. Nie chcę przy tym wpisywać autora Demona ruchu w poczet epigonów romantyzmu. Za oczywisty uznaję znaczny wplyw nauk psychologicznych na twórczość literacką początku XX wieku. Wynika on z uniwersalności psychologii, z rozciągnięcia jej zainteresowań na coraz to nowe obszary ludzkiej działalności, jak i wspomnianej wcześniej popularyzacji tych nauk. W procesie tym szczególne miejsce, zdaniem Bartłomieja Dobroczyńskiego, zajmowała refleksja nad zjawiskami określanymi przeze mnie jako tożsamość katoptryczna:

Zjawisko to, nasilające się wraz z rozwojem psychoanalizy, zdezawuował w 1916 roku Aleister Crowley, pisząc na łamach „Vanity Fair": „Prowadzone są też obserwacje nad wywołaniem depresji u normalnych osób pod wpływem rozmowy o podatkach. [...] Po trwających przez wiele miesięcy żmudnych badaniach odsłoniona zostaje cała natura duszy i już wiadomo, dlaczego ktoś woli jeść czekoladki od cukierków" (idem, Księgi Bestii czyli Eseje filozoficzne Aleistera Crowleya, tłum. D. Misiuna, Wrocław 2000, s. 347).

${ }^{8}$ TLSG, s. 49. Jerzy Eugeniusz Płomieński cytuje list Grabińskiego z 1932 roku, w którym autor sam zestawia swoje teorie z tezami „psychiatry niemieckiego Junga” (J. E. Płomieński, Suweren polskiej fantastyki literackiej. Stefan Grabiński, [w:] idem, Twórcy bez masek. Wspomnienia literackie, Warszawa 1956, s. 115).

${ }^{9}$ K. Irzykowski, Magik niesamowitości. (Po zgonie Stefana Grabińskiego), [w:] idem, Słoń wśród porcelany. Lżejszy kaliber, Kraków 1976, s. 397. 
Wydaje się bowiem, że olbrzymia ilość badań prowadzonych w tym czasie [na początku XX w. - K. G.] nad osobowościami wielokrotnymi, porażeniami histerycznymi, hipnozą, a wcześniej spirytyzmem i magnetyzmem nie tylko nie skłaniała do redukowania ludzkiej psychiki, szukania jakiegoś bardziej podstawowego dla niej substratu, ale wprost przeciwnie: doprowadziła - wespół z pogłębioną refleksją teoretyczną - do powstania nowych koncepcji ludzkiego umysłu, koncepcji, w których najbardziej rzucającą się w oczy cechą była t e n d e n c j a d o poszerzania zakresu zjawisk wchodzących w jejobszar [podkr. - K. G. $]^{10}$

Owo poszerzenie, które Hutnikiewicz traktuje jako racjonalizację metafizyki, w wypadku Grabińskiego proponuję rozumieć nie jako tłumaczenie zjawisk fantastycznych naukowym dyskursem, lecz jako stworzenie warunków, w których zupełnie nieracjonalne zdarzenia czy postaci mogą się zamanifestować. W świecie realnym pojawienie się czegoś niezwykłego wymaga wyjaśnień, gdyż w przeciwnym razie doprowadza do załamania realności. Proponuję odczytywać nowele Grabińskiego bez pretensji do realizmu. Jeśli uznamy je za przestrzeń fantazji, wtedy zbędne będzie tłumaczenie elementów niezwykłych. Staną się one „zwykłe w swej niezwykłości”, ontologicznie poprawne w kontekście marzenia, snu, fantazmatu. Nie przekreśla to roli psychologii, ponieważ materiał ten jest silnie sterowany przez podświadomość. Zatem relacje pomiędzy poszczególnymi elementami świata przedstawionego można - lub nawet należy - odczytywać przy zaangażowaniu narzędzi psychoanalitycznych, lecz nie są one potrzebne do odzierania z fantastyczności.

Kiedy dokonamy takiego „powrotu do fantastyki”, okaże się, że utwory Grabińskiego mają wciąż dużą siłę oddziaływania na czytelnika. Przestają być zapisem przygód realistycznych bohaterów w realistycznym świecie. Zaczynają być rejestrem psychomachii wewnętrznej, potencjalnie dostępnej każdemu człowiekowi - i przez to dużo straszniejszej.

Popularność motywów katoptrycznych w twórczości Grabińskiego była echem badań nad tego typu zagadnieniami. Wydaje się jednak, że jeszcze jeden czynnik wpłynął na częste odwoływanie się do konstrukcji sobowtórowych. Chodzi o pewną pojemność metaforyzacji katoptrycznej. Zawiera ona w sobie potencjał aktualizacji wielu nurtujących zagadnień, umożliwia przywołanie rozmaitych problemów i wskazanie rozwiązań, które czasem stoją względem siebie w sprzeczności. Odbicie wyniesione do rangi filozoficznej, tożsamościowej, i przeniesione na grunt literatury staje się elementem plastycznym i wygodnym dla pisarza.

Wiele treści mieszczących się potencjalnie w literacko wykorzystywanym motywie zwielokrotnienia tożsamości wskazał Zygmunt Freud we fragmencie rozprawy Niesamowite (1997). Twórca psychoanalizy powołuje się na tekst Otto Ranka pod tytułem Der Doppelgänger z 1914 roku i wskazuje na pierwotne wyobrażenia o duszy jako prymitywnej realizacji konstrukcji sobowtórowej. Przypisywana jej rola polegała na usankcjonowaniu ludzkiej nieśmiertelności. Ten specyficzny sobowtór „stanowił pierwotnie zabezpieczenie przed upadkiem «ja», energiczne zdementowanie władzy śmierci” (Rank) - „«dusza nieśmiertelna» była prawdopodobnie pierwszym sobowtórem ciała" ${ }^{11}$. Freud łączy ten pogląd z wykonywaniem rzeźb i innych wizerunków osoby zmarłej w starożytnym Egipcie. Doszukuje się w tym wszystkim przejawu prymarnego narcyzmu, typowego dla dziecka i kultur

\footnotetext{
10 B. Dobroczyński, Ciemna strona psychiki. Geneza i historia idei nieświadomości, Kraków 2001, s. 122.

11 S. Freud, op. cit., s. 247.
} 
pierwotnych. W chwili ewolucji kultury, to znaczy jej wyjścia z fazy narcystycznej, nastąpiło przeniesienie charakteru sobowtóra, „z tego, który zabezpiecza kontynuację życia, staje się on niesamowitym zwiastunem śmierci” ${ }^{\prime 2}$. W ten sposób u podstawy tożsamości katoptrycznej leży jednocześnie nieśmiertelność, czyli wieczne życie, oraz śmierć.

Przepracowanie fazy narcystycznej stwarza możliwość ponownego obsadzenia wyobrażeń sobowtórowych, przyobleczenia ich w nowe treści. „W «ja» kształtuje się z wolna osobliwa instancja, która może się przeciwstawić pozostałemu «ja», która służy samoobserwacji i samokrytyce, która świadczy pracę cenzury psychicznej i jest znana naszej świadomości jako «sumienie»"13. Wyłonienie się sumienia to pewnego rodzaju upostaciowienie Superego. Nie tylko samoobserwacja, także samoocena.

Istnienie sumienia rozumianego jako pewna zewnętrzna względem „ja” instancja możliwe jest w kontekście kartezjańskiego Cogito, to jest podmiotu myślącego, którego podmiotowość na tym właśnie myśleniu się opiera ${ }^{14}$. Jeśli bowiem istnieje „ja”, które myśli i myślenie przekłada na działania albo i nie, oraz coś co owe myśli i działania ocenia (czyli myśli o nich na sposób pozytywny lub negatywny), to również istnieje jako oddzielne ,ja”. „Samoobserwacja” oznacza - w ujęciu kartezjańskim - że istnieję podwójnie, jako ja-obserwujący oraz jako ja-obserwowany. W skrajnej postaci, zwanej przez Freuda „manią obserwacji”, dochodzi do wytworzenia nowej jaźni, instancja sumienia „zostaje izolowana, zostaje odszczepiona od «ja», staje się dostępna obserwacji lekarza"15. Ważną konsekwencją wytworzenia sumienia jako części odrębnej od „ja” jest możliwość rozdzielania cech i treści psychicznych, przy czym Freuda przypomina, że wszelkie treści związane z postacią sobowtóra oznaczone są stygmatem śmierci i rozpadu ${ }^{16}$.

Samoobserwacja i samoocena są sposobem zoperacjonalizowania tożsamości katoptrycznej, ale jednocześnie odsyłają - po raz kolejny - do ujęcia przeciwnego, w którym zawiera się ich negacja. Nie tylko sumienie obserwujące oddziela się od „ja” obserwowanego, sam proces obserwacji prowadzi do porażki. Okazuje się, że istnieją treści niemożliwe do oglądu, pewne rejony obce Cogito. Pojawia się też tendencja do wartościowania. Ujmowanie psychiki w kategoriach dualistycznych prowadzi do wydzielenia „lepszej” części oraz „gorszej”" "Gorszą” (irracjonalną i cielesną) opisuje się jako niekontrolowaną, co burzy mit doskonałej samokontroli człowieka, lecz zarazem zwalnia go z obciążeń moralnych ${ }^{18}$. $\mathrm{W}$ ten sposób wyłania się idea nieświadomości.

Wychodząc od samowiedzy, która w idealnym wyobrażeniu miała stać się udziałem podwojonego ,ja”, dochodzimy poprzez fiasko autoanalizy do odkrycia obecności treści nieświadomych, stanowiących kolejną duplikację. Freud wskazuje na rozmaitość treści nieuświadomionych, a co za tym idzie - na mnogość charakteru sobowtóra będącego już nie instancją wewnętrzną, ale heautoskopową manifestacją nieświadomości ${ }^{19}$. Sobowtór

\footnotetext{
12 Ibidem.

13 Ibidem.

14 M. Foucault, Człowiek i jego sobowtóry, tłum. T. Komendant, "Literatura na Świecie” 1988, nr 6, s. 200-234 .

15 S. Freud, op. cit., s. 248.

16 Ibidem.

17 B. Dobroczyński, op. cit., s. 146.

18 Zob. I. Możejko, Odbicie, cień, sobowtór. Znaki dwuwymiarowości istnienia w młodopolskiej liryce Leopolda Staffa, [w:] Pośród twórczych potęg i niszczących mocy. Antynomiczne widzenie rzeczywistości w literaturze Młodej Polski, red. G. Igliński, R. Świątkowski, Olsztyn 2005, s. 174.

19 S. Freud, op. cit., s. 248.
} 
w tym ujęciu staje się materializacją wszelkich niespełnień podmiotu, jest potencją „ja” nieograniczoną kontekstem. Ponieważ zestawienie tak wyprojektowanego sobowtóra z oryginalnym podmiotem wypada na korzyść sobowtóra, rodzi się pytanie: dlaczego podmiot nie jest swym sobowtórem, skoro ten jest lepszy i bycie nim jawi się jako korzystniejsze? Freud udziela następującej odpowiedzi: oczywiście podmiot c h c i a ł b y być swym sobowtórem, bo jest on (w tym konkretnym ujęciu!) realizacją jego niespełnionych pragnień, ale jednocześnie n i e m o ż e nim być, ponieważ w swych dążeniach podmiot ograniczony jest i hamowany przez zewnętrzne, niezależne od niego okoliczności. Idealne odbicie jest świadectwem determinizmu podmiotu i dlatego obala mit wolnej woli.

Wreszcie popularność motywów katoptrycznych wynika po części z charakterystycznych dla końca XIX wieku i aktualnych do dziś problemów z określeniem „ja”. Silnie zarysowały się wtedy skrajne poglądy podające $\mathrm{w}$ wątpliwość, a czasem otwarcie negujące istnienie ,ja”.

Pytania o istnienie „ja”, jego zasadność i podstawę sprzyjały literackiej egzemplifikacji pod postacią czy to sobowtóra, czy duszy, czy innego przejawu tożsamości katoptrycznej. Zdwojenie, a bardziej jeszcze zwielokrotnienie, w plastyczny sposób ukazywało dylematy związane z określaniem osobowości; jeśli nie negowało, to rozbijało „ja”, komplikowało jego sytuację.

Wszystkie te użycia konstrukcji katoptrycznych wiążą się poniekąd z rozczarowaniem pozytywistycznym paradygmatem naukowym. Nauka bowiem, mimo wszelkich starań, nie zdołała zapewnić spójnego, ugruntowanego obrazu „ja”. Okazało się, że nie wszystko można objąć rozumem, a to, czego nie można, powraca jako sobowtór.

Obecność interesujących nas motywów dostrzec można już w pierwszym zbiorze opowiadań Grabińskiego, Na wzgórzu róż z 1918 roku$^{20}$. Bohater opowiadania Po stycznej, Wrzecki, przebywszy chorobę mózgu, wykazuje nadmierną pobudliwość intelektualno-teoretyczną. Nadaje on sens wszelkim przypadkowym zdarzeniom, które dostrzega jako elementy kosmicznego ciągu. W opowiadaniu towarzyszymy Wrzeckiemu podczas przechadzki, która kończy się jego śmiercią. Wcześniej bohater spotyka na swej drodze pijaka biorącego go przez pomyłkę za swego przyjaciela. Utożsamienie to staje się fatalne w skutkach. Dla osoby, która wszystkie zjawiska interpretuje jako część kosmicznego planu, taka pomyłka jest niezwykle znacząca - i rzeczywiście, to i kilka podobnych wydarzeń zakończy się samobójstwem. Podobieństwo do osoby zmarłej nie tylko determinuje samobójstwo bohatera, ale jednocześnie naznacza go stygmatem śmierci, tak że dla innych staje się w jakiś sposób jej zwiastunem, obecnością ${ }^{21}$.

Te zalążki problemów katoptrycznych znalazły rozwinięcie w dwóch innych nowelach $\mathrm{z}$ tego samego tomu: Zez oraz $W$ willi nad morzem. W pierwszej swoją historię relacjonuje pierwszoosobowy, nienazwany z imienia narrator. Zaczyna od opisania Brzechwy - złośliwej, zezowatej osoby uparcie szukającej towarzystwa narratora. Relacja między nimi jest o tyle trudna, że posiadają zupełnie różne, przeciwstawne cechy charakteru. Brzechwa to

20 W roku 1909 Grabiński, pod pseudonimem Stefan Żalny, wydał niewielki tom pt. Z wyjątków. W pomrokach wiary. Dzieło to, wykazujące jeszcze silne niedostatki pod względem formy, przeszło bez uwagi ze strony krytyki. Dlatego za debiut Grabińskiego przyjęło się uważać Na wzgórzu róż. Zob. TLSG, s. 13.

${ }^{21}$ "W wierzeniach rozmaitych ludów ujrzenie swego obrazu bądź utrata cienia grozi śmiertelnym niebezpieczeństwem" (Z. Majchrowski, Sobowtór, [hasło w:] Słownik literatury polskiej XIX wieku, red. J. Bachórz, A. Kowalczykowa, Wrocław 2002, s. 884), a więc w ludowym ujęciu sobowtór także w pewien sposób związany jest z zapowiedzią śmierci. 


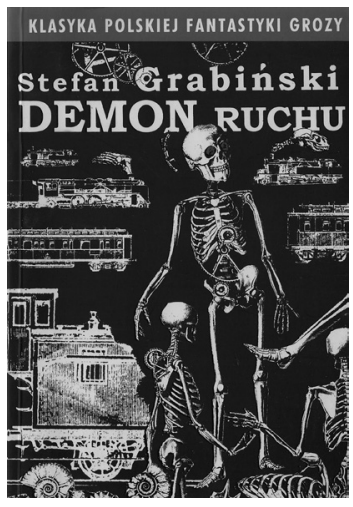

S. Grabiński, Demon

ruchu, posł. Krzysztof Varga, Wydawnictwo Lampa i Iskra Boża, Warszawa 1999 „żyjąca antyteza” narratora. Dwie osoby, z których jedna jest przeciwieństwem drugiej, nasuwa skojarzenia $\mathrm{z}$ lustrzanym odbiciem. $\mathrm{Z}$ czasem narrator zaczyna postrzegać Brzechwę jako byt nie tyle indywidualny, co zbudowany na jego (narratora) osobowości. W ten sposób odrealnia jego istnienie, stwierdza nawet: „począłem przed nim uczuwać pewien rodzaj zabobonnego strachu i uważać go za swego złego ducha czy demona” (N, s. 40).

Najczęściej powracającym tematem sporów, jakie narrator prowadził z Brzechwą, „osią antagonizmu", była kwestia indywidualizmu:

Byłem zagorzałym wielbicielem wszystkiego, co osobiste, oryginalne, jedyne, w sobie zamknięte - Brzechwa, przeciwnie, szydził z wszelkiego indywidualizmu, uważając go za chimerę zarozumiałych półgłówków; stąd nie wierzył w żadną inwencję, pomysłowość, sprowadzając je do wykładników wpływów środowiska, rasy, tzw. ducha czasów itp. [N, s. 40].

Przytoczona przez narratora wypowiedź Brzechwy, będąca jego ostatecznym zdaniem w sporze, stanowi zarazem główny problem Zeza: „Przypuszczam nawet - cedził niejednokrotnie, zezując w moją stronę - że w każdym z nas siedzi kilka indywiduów i drze się o marny ochłap tzw. duszy" (N, s. 41). Kwestia indywidualności jest zagadnieniem centralnym nie tylko tego opowiadania, ale także całej twórczości Grabińskiego ${ }^{22}$. Wprowadzenie w jego obręb elementów katoptrycznych komplikuje problem, ponieważ z perspektywy Brzechwy podmiot nie tylko jest zwielokrotniony sam w sobie, ale także każde z tych zwielokrotnień jest zaledwie odbiciem zewnętrznych okoliczności i wpływów.

W dalszej części opowiadania Brzechwa ginie w pojedynku, do którego doszło pośrednio za sprawą narratora. Po tym wydarzeniu narrator cierpi na zapalenie mózgu. Wyraźny to objaw żałobnej identyfikacji, to znaczy utożsamienia się z osobą zmarłą poprzez stan chorobowy. Wyszedłszy z choroby, bohater nieoczekiwanie zaczyna przejawiać cechy zmarłego prześladowcy. Przerażony tymi zmianami szuka ratunku w alienacji i literaturze. Rozpoczyna walkę o własną tożsamość. Jednak jego głębokie skupienie przerywa każdorazowo bliżej nieokreślony dźwięk. W końcu odkrywa w swym mieszkaniu sekretny pokój. Przebiwszy się do niego, widzi Brzechwę, który wchodzi w ciało narratora. Opowiadanie kończy się kolejnym dziwnym dźwiękiem. Po czasie narrator rozpoznaje go jako jego „własny” śmiech.

Zez stawia problem tożsamości i indywidualizmu, lecz zatrzymuje się na jego wyartykułowaniu. Bohater odkrywa w sobie istnienie drugiej, obcej, zdwojonej osoby, jednak autor nie podejmuje jeszcze próby odpowiedzi na pytanie o jej naturę. Poszukiwania źródeł „inności w sobie” pojawią się dopiero w późniejszej twórczości Stefana Grabińskiego.

Ciekawym ujęciem katoptryzmu jest wspomniane już opowiadanie $W$ willi nad morzem. Ma ono dość skomplikowaną konstrukcję, gdyż kluczowa dla tekstu postać jest nieobecna. Poeta, Stanisław Prandota, zginął na pokładzie statku w czasie poprzedzającym fabułę. Autor sprawia, że czytelnik - trochę jak w powieści kryminalnej - wraz z rozwojem zdarzeń odkrywa coraz to nowe okoliczności śmierci Prandoty. I choć prawda nie zostaje przedstawiona bezpośrednio, to domysły budują scenę śmierci zupełnie odmienną od pierwotnie poznanej.

22 M. Adamiec, „Cień wielkiej tajemnicy”. Rzecz o opowieściach Stefana Grabińskiego, „Twórczość” 1982, nr 7, s. 106. 
Narrator znów jest bezpośrednim uczestnikiem wydarzeń. Spędza czas w tytułowej willi swego przyjaciela, Norskiego. Gdy pewnego dnia Norski odczytuje swe wiersze, narrator dostrzega w nich podobieństwo do twórczości Prandoty. Wkrótce jednak sytuacja ulega odwróceniu i to w zachowaniu narratora Norski - ku swemu przerażeniu - dostrzega podobieństwo do ich wspólnego zmarlego przyjaciela.

Na dzień przed wyjazdem narratora odbywa się uroczysta kolacja, w czasie której nieopatrznie bohater w żartach posądza Norskiego o próbę otrucia. Uwaga ta głęboko dotyka gospodarza. Wieczorem narrator rozmawia z Adasiem, synem Norskiego, który pokazuje mu medalik otrzymany niegdyś od Prandoty oraz - grób poety! Okazuje się, że Prandota nie zginął na morzu, lecz najprawdopodobniej został otruty przez Norskiego. Powodem morderstwa była zemsta na artyście za uwiedzenie żony gospodarza, także nieżyjącej już Róży. Być może owocem tego romansu były narodziny Adasia, przypominającego z rysów Prandotę. Zdemaskowany morderca popełnia samobójstwo.

Choć Prandota nie pojawia się bezpośrednio na kartach opowiadania, to jednak jego postać odbija się w każdym z trójki bohaterów: w narratorze, Norskim i Adasiu. Narrator przejmuje jego gesty i upodobania, Adaś jest jego synem, fizycznie przypomina ojca, Norski tworzy poezję podobną do dorobku zmarłego, ostatecznie zaś popełnia samobójstwo, utożsamiając się z nim w śmierci. Prandota jest w pełni obecny poprzez swoje „odbicia” $\mathrm{w}$ pozostałych bohaterach. W przeciwieństwie do noweli Zez, tutaj autor zrezygnował $\mathrm{z}$ ukazania sposobu, $\mathrm{w}$ jaki poszczególne postaci reagują na zachodzące w nich przemiany.

Wyraźnych sytuacji katoptrycznych nie znajdziemy w drugim tomie opowiadań Grabińskiego pt. Demon ruchu z 1919 roku. Zamieszczone tu historie związane są w różny sposób z życiem kolei, co być może dostarczyło autorowi tak dużej ilości materiału, że odsunął na bok rozważania nad wielokrotnością ludzkiej tożsamości. Znacznie więcej odbić i zwielokrotnień pojawia się w kolejnym zbiorze - Szalonym pątniku z roku 1920. To z niego pochodzą omawiane w dalszej części tekstu opowiadania: Problemat Czelawy i Dziedzina.

Innym tytułem, na który warto zwrócić uwagę, jest Saturnin Sektor. Historia ta - dziwna nawet jak na twórczość Grabińskiego - dotyczy sporu pomiędzy dwoma szaleńcami. Przedmiotem konfliktu jest zagadnienie czasu, a miejscem ścierania się - lokalna gazeta, w której oponenci publikują swe artykuły i polemiki. W końcu główny bohater, przekonany o nieistnieniu czasu, odnajduje swego przeciwnika w osobie starego zegarmistrza. Wdają się w długą wymianę zdań, dochodząc wreszcie do konkluzji:

- Nie zrozumiemy się nigdy. Rzecz szczególna! Mimo że jestestwa nasze tak są ze sobą dziwnie splecione. [...] Gdyby nie to - ciągnął zgaszonym głosem starzec - że myśli twoje wyglądają na młody szczep zasadzony na moim pniu, gdyby nie to, że przeczuwam ich rozbłysk w najbliższej przyszłości...

- To co?

- Zabiłbym cię - odpowiedział zimno. - Tym oto narzędziem.

I wydobył z pluszowego puzdra cudnej roboty puginał z rękojeścią z kości słoniowej.

Uśmiechnąłem się tryumfująco:

- Tymczasem role wypadają odwrotnie.

Starzec pochylił z rezygnacją głowę:

- B o przezwyciężyłeś mnie w sobie... [N, s. 276]

I rzeczywiście następnego dnia rano zegarmistrz zostaje odnaleziony martwy, przy czym w relacjach $\mathrm{z}$ wieczornych gazet zadawano sobie pytanie, czy było to morderstwo czy samobójstwo? 
Poprzez alegoryczne ujęcie czasu wprowadził Grabiński zagadnienie konfliktu pokoleń. Spór zegarmistrza z głównym bohaterem do złudzenia przypomina walkę pozytywistów z młodopolanami, jaka miała miejsce na przełomie XIX i XX wieku, lub wcześniejszy spór klasyków z romantykami. Wplecenie pewnych elementów katoptrycznych nadaje dyskusji nowy ton. Autor nie zajmuje żadnego stanowiska, nikomu nie przyznaje wyraźnej racji. Saturnin Sektor pokazuje raczej, iż każde pokolenie jednocześnie odbija się w pokoleniu późniejszym i jest odbiciem pokolenia wcześniejszego. Zegarmistrz i bohater są jedną osobą (na co wskazuje fakt, że obaj są szaleni, przytoczony wyżej fragment dialogu, zabójstwo, które jest samobójstwem itd.) o dwóch różnych aspektach.

Zajmująco przedstawia się ostateczna reintegracja. Po śmierci zegarmistrza miasto obiega osobliwa wiadomość w „żałobnych klepsydrach” informujących o „zgonie Czasu” (N, s. 278). Można w tym dostrzec nieczęstą u Grabińskiego grę językową: zgon c z a s u głoszony jest przez k l e p s y d r ę. Dzięki podwójnemu znaczeniu słowa „klepsydra” możemy odczytać ten paradoks jako znak reintegracji - w śmierci.

W Księdze ognia (1922) znalazły się opowiadania w różny sposób związane z tym żywiołem oraz ludźmi mającymi z nim do czynienia: strażakami, kominiarzami itp. Podobnie jak w wypadku Demona ruchu, także tutaj przyjęta tematyka nie sprzyjała wprowadzaniu wątków katoptrycznych. Wyjątek stanowi opowiadanie Muzeum dusz czyśćcowych.

Głównym bohaterem jest doktor Proń, naukowiec i okultysta, który przybywa do prowadzonego przez pewnego proboszcza muzeum. Proboszcz zbiera ślady dusz przebywających w czyśćcu: jego zdaniem znajdujący się tam zmarli czasem pojawiają się na planie materialnym i dają wyraz swoim mękom poprzez wypalanie różnych znaków (dłoni, twarzy) za pomocą ognia piekielnego. Przedmioty z takimi śladami stanowią eksponaty w tytułowym muzeum dusz czyśćcowych. Proń nie wierzy w tłumaczenia księdza i źródeł tajemniczych znaków dopatruje się w zjawiskach spirytualistycznych. Wkrótce odkrywa, że bratanica proboszcza, Helena, posiada zdolności mediumistyczne.

Jednym z eksponatów muzealnych jest wypalony w materiale wizerunek pewnego $\mathrm{XV}$-wiecznego kardynała, który pojawił się $\mathrm{w}$ trakcie mszy odprawianej przez właściciela muzeum. Proboszcz jest niezwykle podobny do kardynała, a ponadto zna fakty z odległej historii Rzymu, nigdy niebędącej przedmiotem jego studiów. Proń rozpoczyna seanse z Heleną. Podczas jednego z nich ukazuje się widmo kardynała, które po chwili przemienia się w proboszcza. Kiedy Helena wychodzi z transu, udają się do księdza, lecz ten już nie żyje.

W noweli Grabiński przywołuje motyw reinkarnacji, który w jego twórczości powraca na przykład w Wyspie Itongo. Zestawienie jej z odbiciem stawia nowe pytania: jak wiele $\mathrm{z}$ doświadczeń wcześniejszych wcieleń obecnych jest w podmiocie? Czy w ogóle nie stanowi on pewnej karmicznej wypadkowej, która nie tylko determinuje jego losy, ale także charakter i osobowość? To oczywiście kwestie związane z tożsamością katoptryczną: ile różnych „ja” jest we mnie obecnych? Reintegracja po raz kolejny odbywa się w chwili śmierci, jednak tym razem odsyła ona do nowej jakości, tzn. do potencjalnie nowego wcielenia proboszcza-kardynała ${ }^{23}$.

Pochodzący z tego samego roku co Księga ognia wybór nowel zatytułowany Niesamowita opowieść przynosi kolejne odsłony rozmaitych ujęć tożsamości katoptrycznej. Dwa z nich doczekały się już osobnych interpretacji i nie ma potrzeby ich tutaj obszernie przywoływać

\footnotetext{
23 Pewnym paradoksem jest, że obie inkarnacje to osoby duchowne w tradycji chrześcijańskiej, która koncepcję reinkarnacji odrzuca.
} 
lub powtarzać. Kochance Szamoty poświęcona jest część Fantazmów Krystyny Kłosińskiej i choć opracowanie to nie wprowadza kategorii tożsamości katoptrycznej, to czytelnik bez problemów odnajdzie w nim wątki odbicia, jeśli tylko zjawę Jadwigi potraktuje bądź to jako emanację Animy, bądź zewnętrzny symptom Jerzego Szamoty ${ }^{24}$.

Drugie opowiadanie to $W$ domu Sary, o którym dużo pisała Barbara Zwolińska w książce Wampiryzm w literaturze romantycznej i postromantycznej. Tytułowa Sara rzeczywiście jest swego rodzaju wampirem, utrzymującym się przy życiu dzięki energii seksualnej odbieranej swym kolejnym kochankom. Wykorzystany tu element katoptryczny polega na tym, że wampirzyca w pewien sposób odzwierciedla wygląd każdej ze swych ofiar.

W Niesamowitej opowieści zawarta jest jeszcze jedna nowela, pt. Na tropie, której - ze względu na ciekawą konstrukcję katoptryczną - warto przyjrzeć się nieco bliżej. Jej bohaterem jest malarz, w wolnych chwilach eksperymentujący z hipnozą. Po jednej z takich sesji budzi się rano, nie pamiętając, jak spędził noc. W porannej gazecie czyta wzmiankę o morderstwie dokonanym kilka godzin wcześniej na hrabiance, którą niegdyś portretował. Zaciekawiony artysta udaje się na miejsce zbrodni, gdzie napotyka na ślad mordercy. Idąc za tropem, kluczy po okolicy, by na koniec stanąć przerażony pod własnym domem.

Mamy tu do czynienia nie tyle z rozbiciem jaźni czy emanacją jakichś treści psychicznych na zewnątrz bohatera, ile z przejęciem kontroli przez podświadomośćs ${ }^{25}$. Całość wiąże się oczywiście z hipnozą, o której Dobroczyński pisze:

Zwłaszcza hipnoza $[\ldots]$ stała się narzędziem, które - dzięki nieoczekiwanemu wpływowi na ludzkie zachowania - nazwano „królewską drogą do nieświadomości”. Szczególnie istotne były tu zauważone przez psychiatrów trudności, jakie miały osoby uprzednio zahipnotyzowane z podaniem motywów zachowań zasugerowanych im przez hipnotyzera ${ }^{26}$.

Jeśli jednak hipnotyzer i pozostający pod wpływem hipnozy to jedna i ta sama osoba (co już jest pewnym rozdwojeniem), to w obszar sugestii dostać się mogą właśnie wszelkiego rodzaju pragnienia, marzenia, fantazje i treści wyparte do podświadomości. Treści te są często powiązane z popędami, w tym i seksualnymi. Dobroczyński wskazuje na ich znaczną „energetyczność”:

„Nieświadome” [...] składa się z życzeń czy też pragnień obdarzonych pewną ilością energii; nie zna takich stanów, jak wahanie, przeczenie czy wątpliwość; nie posiada logiki, dzięki czemu może zawierać sprzeczne tendencje i motywacje; dysponuje niemal nieograniczoną ilością energii; zawiera procesy pozaczasowe i niezniszczalne; idea czasu nie ma zastosowania do nieświadomości; [...] działa zgodnie z zasadą przyjemności - całkowicie lekceważąc wymagania stawiane przez rzeczywistość zewnętrzną $[\ldots]^{27}$.

Dzięki tym uwagom możliwe jest nie tyle wyjaśnianie, co zaakceptowanie irracjonalnych okoliczności morderstwa: drzwi hrabianki zaryglowane od wewnątrz pozostały w stanie

${ }^{24}$ W takim znaczeniu, w jakim Kobieta jest symptomem mężczyzny u Lacana.

25 Lub: utratą kontroli przez świadomość. Kontrola kojarzy się z pewnym zahamowaniem, ograniczeniem, co wiąże się z rolą świadomości. Tymczasem podświadomość jest niepohamowana, jest sama w sobie zupełnym brakiem kontroli.

26 B. Dobroczyński, op. cit., s. 113-114.

27 Ibidem, s. 91.
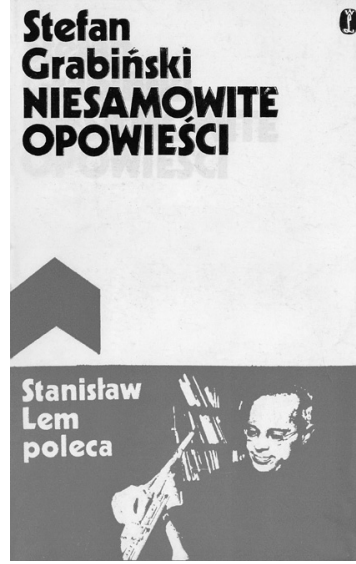

S. Grabiński, Niesamowite opowieści, posł. Stanisław Lem, Wydawnictwo Literackie, Kraków 1975 


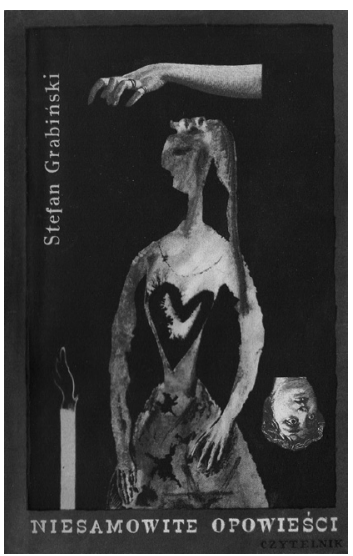

\section{S. Grabiński, Niesamowite}

opowieści, wyb. i oprac. Janusz Wilhelmi, Czytelnik, Warszawa 1958 nienaruszonym, jedyna droga do pokoju prowadziła przez okna, ale i te znaleziono pozamykane. By dostać się do samego zamku, zbrodniarz musiał pokonać wielometrowy mur. I wreszcie - śmiertelny cios był wymierzony prosto w serce, a zarazem tak silny, że hrabianka zmarła nie zdążywszy się nawet przebudzić.

Z racjonalnego punktu widzenia okoliczności te trudne są do wytłumaczenia. Jednakże bohater „opętany” przez podświadomość nie postępował racjonalnie. Energia, jaką wyzwalał podczas hipnozy, mogła obdarzyć go nadludzką siłą i sprawnością.

Opowiadanie to ważne jest w dorobku Grabińskiego rozpatrywanym pod kątem tożsamości katoptrycznej o tyle, że dzięki zastosowaniu motywu hipnozy nie mamy tu do czynienia z metaforyczną projekcją części tożsamości bohatera. Początkowo wydaje się, co prawda, że śledzi on inną osobę, ale w zakończeniu dowiadujemy się wprost, że tak naprawdę śledził samego siebie. Przy czym świadomość ta ma charakter traumatyczny.

\section{Potworzenie}

Jedną z najpopularniejszych realizacji tożsamości katoptrycznej w literaturze jest motyw sobowtóra lub bliźniaka. Sytuacja w tekście jest wtedy klarowna: mamy dwóch bohaterów, których wygląd jest identyczny lub bardzo zbliżony. Fizycznie stanowią osobne indywidua realne i materialne. Dopiero w sferze psychiki można zaobserwować komplikacje. Bo jeśli posiadają ten sam wygląd, to samo ( $w$ wypadku bliźniaków) pochodzenie, te same - powiedzielibyśmy dziś - geny, to czy ich życie wewnętrzne także przebiega podobnie? Czy ich psychika kształtuje się symetrycznie, tak jak ciało? Literatura znajdowała szereg różnych, czasem sprzecznych odpowiedzi.

Podejmując problem bliźniactwa, Grabiński postanowił twórczo go przebudować ${ }^{28}$. Bliźniacy z opowiadania Problemat Czelawy wyróżniają się tym, że posiadając dwa ciała, dwie tożsamości, mają tylko jedną świadomość, która wędruje od jednego do drugiego z nich.

Mimo iż bracia dorastali wspólnie, najpierw przy rodzicach, a po ich śmierci wyjechawszy za granicę, nie mieli przecież ze sobą kontaktu. Nie rozmawiali ze sobą ani przez minutę, nikt ich nie widział jednocześnie, a dla nich nawzajem widok pogrążonego w podobnym do śmierci letargu brata o identycznym wyglądzie musiał być co najmniej nieprzyjemny. Niemożliwe było zbudowanie familijnej więzi. Dlatego w sytuacji tej powinniśmy mówić raczej o sobowtórach niż o braciach bliźniakach. Odrzucenie braterstwa powoduje, że puste miejsce zostaje wypełnione przez konflikt. Nie mogąc uwolnić się od siebie wzajemnie, zaczynają się nienawidzić29. Zgadza się to z tekstem, w którym określenie „bliźniak” pojawia się tylko na początku (N, s. 258), podczas gdy w pozostałych sytuacjach używa się konsekwentnie słowa „sobowtór”"

${ }^{28}$ Zgodnie ze swymi zapatrywaniami na kwestię oryginalności w sztuce, zob. S. Grabiński, Zagadnienie oryginalności w twórczości literackiej, „Pamiętnik Literacki” 1925/1926, s. 1-4.

29 Zob. R. Girard, Od mimetycznego pożądania do upiornego sobowtóra, [w:] idem, Sacrum i przemoc, tłum. M. i J. Plecińscy, Poznań 1993, s. 221.

${ }^{30}$ Co ciekawe, gdy w tekście pojawia się wyrażenie "brat Stachur" (N, s. 255, 257), to nie dotyczy ono pokrewieństwa łączącego go z Czelawą, ale więzi między nim a przedstawicielami „braci przestępczej”, zbiorowością lokalnych opryszków. 
Fakt, że jeden z braci pozostawał aktywny nocą (od godziny 20 do 8), drugi zaś za dnia (od 8 do 20), jest niezwykle znaczący. To element decydujący o rozwoju osobowości obu bohaterów.

Konieczność życia nocą ukształtowała charakter Stachura. Stał się bywalcem oberż, gdzie nocami zbierało się środowisko przestępcze. Z czasem sam zaczął łamać prawo, rozbudziły się w nim mordercze instynkty oraz erotyczna rozwiązłość. Odwrotnie było w wypadku „dziennego” brata - Czelawy. Nie wykazywał on w ogóle aktywności seksualnej, wszelkie rozrywki - czy to wysokie jak teatr, czy też niskie, dostarczane przez gospody były mu raczej obce, gdyż już o 20 zapadał w letarg. Hulaszcze życie rówieśników stało się dla niego niedostępne. Kompensatę odnalazł w nauce, co zaowocowało doskonałymi wynikami i błyskawiczną karierą w stosunkowo młodym wieku.

Zróżnicowanie charakterów pociągnęło za sobą różnice w wyglądzie ${ }^{31}$. Występują one od samego początku: ponieważ bracia urodzili się zrośnięci biodrami, zostali rozdzieleni operacyjnie, lecz po pierwotnym zrośnięciu pozostały ślady w postaci „szerokiej blizny” (N, s. 243) oraz utykanie na jedną nogę. Czelawa lekko utyka na nogę prawą, Stachur - na lewą. Różnica ta przywodzi na myśl lustrzane odbicie, w którym lewa strona patrzącego staje się prawą stroną odbicia i odwrotnie. Blizna symbolizuje brak tego, co ma (czym jest) brat, a utykanie to nieustanne przypominanie o defekcie, o swoistej niekompletności.

Oprócz różnic występujących tuż po porodzie istnieją także te, które wykształciły się i pogłębiły z biegiem czasu. Tryb życia i charakter sprawiły, że twarz Stachura pokryła się bliznami, nadużywanie alkoholu także pozostawiło swoje ślady. Czelawę, prowadzącego ascetyczny żywot intelektualisty, charakteryzowała nienaganna prezencja.

Kariera Czelawy, jego aktywność społeczna doprowadziły z czasem do podporządkowania Stachura, który za dnia zdany był na łaskę profesora. Ten ukrywał go zamkniętego w swojej pracowni przed całym światem, nawet własną żoną. Ciężar, jaki bliźniak stanowił dla naukowca, obrócił się paradoksalnie w źródło jego sukcesów, gdy Czelawa postanowił wykorzystać bogaty materiał wspomnień i informacji dostarczanych do jego pamięci w czasie aktywności Stachura. Ta osobliwa symbioza zacieśniana była przez zależność finansową: Stachur, nie mając możliwości pracy w nocy, otrzymywał niewielką zapłatę za przysłuchiwanie się nocnym opowieściom rozmaitych przestępców i dewiantów. Dzięki tym informacjom Czelawa stał się wybitnym specjalistą z dziedziny psychopatologii. Ostatecznie posunął się jeszcze o krok dalej i ze swej relacji ze Stachurem uczynił temat pracy naukowej, która miała mu przynieść sławę. To, co początkowo stanowiło dla Czelawy inicjalny powód zajęcia się nauką, trwało jako motywacja do intelektualnego rozwoju, przerodziło się w źródło zawodowych sukcesów, finalnie miało zaistnieć (i zaistniało) jako obiekt rozważań, które uczynity naukowca sławnym.

Już pierwotne rozróżnienie na dzień i noc, leżące u początku historii Czelawy/Stachura, nasuwa konotacje psychoanalityczne. Pociągane przez tę dychotomię kwestie seksualnej

${ }^{31}$ Pogląd, według którego charakter i aparycja są ze sobą sprzężone, nie jest nowy. Już William Blake uważał, że powłoka cielesna jest kompromisem między materią a duchem - im silniejszy duch, tym piękniejsze ciało. W Młodej Polsce rozwinęła się osobna pseudonauka badająca tego typu zależności: fizjognomia. Motyw przemiany wyglądu pod wpływem zbrodniczych uczynków pojawia się m.in. w powieści Oscara Wilde’a Portret Doriana Greya. U Grabińskiego można usłyszeć echo tego typu poglądów: „Bo temat-pomysł uwarunkowuje formę, nie odwrotnie, podobnie jak duch kształtuje ciało" (S. Grabiński, Zagadnienie oryginalności..., s. 2), jeszcze dobitniej wypowiada się mag Wieriusz z powieści Salamandra: „Ciało powinno iść za duszą, a organizm kształtować się w planie zasady. Myśl stwarza ciało i jego fizyczne predyspozycje” (S, s. 8). 
aktywności i oziębłości, rozwoju intelektualnego i morderczych instynktów oraz cały szereg zarówno podstawowych, jak i szczegółowych różnic pomiędzy bliźniakami utwierdza w przekonaniu, że zasadne będzie sprowadzenie ogółu zaistniałych ambiwalencji do opozycji pomiędzy Superego i Id.

Czelawa jawi się w tekście jako uosobienie Superego. Brak w nim elementów typowych dla $I d$, które całościowo osadzone są w sobowtórowej figurze Stachura. Czelawa jako intelektualista, profesor psychologii, wybitny psychopatolog pracujący na uniwersytecie wyraźnie stanowi tę część wspólnej tożsamości Czelawy-Stachura, która podlega społecznej nobilitacji. Stachur z kolei nie tylko dostarcza profesorowi materiał badawczy, ale także a może nawet przede wszystkim - jest istotą poddającą się wszystkim zwierzęcym instynktom $^{32}$ wpisanym w tożsamość jako integralna część, niemożliwa do zupełnego wykluczenia.

Ponieważ pamięć jest elementem wspólnym, spajającym całą sobowtórową konstrukcję, Stachur ma dostęp do wiedzy profesora, przez co w pewien sposób jest powiązany z Superego. Inaczej rzecz wygląda w przypadku Czelawy. Nawet jego małżeństwo wydaje się spełniać funkcję czysto socjalną poprzez realizowanie jakiejś społecznej konwencji. Jego życie seksualne w zasadzie nie istnieje, mimo że sankcjonowane małżeństwem byłoby dopuszczalne obyczajowo. Nawet rozrywka, której poddaje się profesor i która staje się pretekstem do jego spotkania z narratorem, jest intelektualną, pełną zasad i praw, pozbawioną spontaniczności i fizyczności grą w szachy.

Rozdźwięk między sferą Superego a Id pojawia się także w kwestii tak podstawowej jak nazewnictwo. Pierwotne rozróżnienie jest proste i wpisuje się doskonale w omawiany tu podział. „Profesor Czelawa”, czyli nazwisko, coś urzędowego, oficjalnego, uznanego prawnie, dodatkowo wzmocnione przez tytuł naukowy. „Stachur” to raczej nie imię, tylko przezwisko - nieformalne, nadane wśród opryszków zbierających się po karczmach.

Problem z imionami (a w zasadzie z nazwiskiem i przezwiskiem - wszak żadne z nich nie jest imieniem) pojawia się w dwóch wypadkach. Pierwszy to wyznanie pani Wandy, żony Czelawy: „Krzyknęłam instynktowo szukając ręki śpiącego na sąsiednim łóżku męża. Znalazłam ją trupio zimną, jak zwykle u niego podczas snu - lecz Stach nie obudził się" (N, s. 237) oraz „[g]dy widmo rozwiało się zapaliłam lampę, by przekonać się, że Stach spoczywa rozebrany tuż obok w głębokim jak zwykle uśpieniu" (N, s. 238). Nietypowa forma imienia - Stach - może wynikać z bliskości relacji, w jakich z profesorem pozostaje pani Wanda. Jednakże zwykła ona mówić o Czelawie „mój mąż” i jest w tym dość konsekwentna podczas rozmów z narratorem. Odstępstwa powyżej przytoczone mają miejsce w sytuacji szczególnej: profesor śpi rozebrany na łóżku, u boku swojej żony, gdy w sypialni zjawia się Stachur. Nie bez znaczenia jest fakt, że na tym etapie rozwoju fabuly pani Wanda uważa jeszcze Stachura za swoją halucynację, której treścią jest jej mąż. Postać mierzy ją wzrokiem przepełnionym „ohydny[m] cynizm[em] i lubieżnoś[cią]” (N, s. 238). Wanda nazywa Czelawę Stachem w okolicznościach specyficznych, przepojonych erotyzmem: kiedy jej mąż leży rozebrany na łóżku, a jego widmo spogląda na nią „lubieżnie”. W chwili erotycznego napięcia status Superego zostaje zachwiany i to tłumaczy zmianę nazewnictwa. „Stach” zbliża Czelawę do Stachura i jest to przemiana najzupełniej uzasadniona, choć w wypadku pani Wandy - nieświadoma.

${ }^{32}$ Metaforyka odwołująca się do świata zwierzęcego często pojawia się w opisach Stachura: „[ze] zwierzęco-namiętnym uśmiechem"; „, inteligencja uczonego weszła tu w dziwaczny sojusz z rozbestwieniem”; „Ostre białe zęby, jak kły rozwścieczonego dzika" (N, s. 238, 246, 261). 
Druga komplikacja kwestii imienia jest zarazem klamrą spinającą opowiadanie. Oto jego pierwszy akapit:

Onegdaj po południu o zwykłej godzinie ordynacyjnej przyjąłem kolejną pacjentkę: zaszczyciła swą wizytą mnie, początkującego neurologa, pani Wanda Czelawa, żona powszechnie znanego profesora dr. S. W. Czelawy, który od szeregu już lat, zajmując katedrę filozofii w naszym mieście, zdobył sobie sławę wybitnego badacza z dziedziny psychopatologii [N, s. 232]

oraz ostatni: „W dwa lata potem wydało londyńskie towarzystwo naukowe dzieło prof. W. S. Czelawy pod tytułem: The Soul and the body or The history of a man with two bodies. The probleme of my life. Do tekstu dolączył autor dwie podobizny. Swoją i brata Stachura" (N, s. 265). Skąd ta nagła zmiana szyku imion? Dlaczego Stanisław Władysław ${ }^{33}$ stał się Władysławem Stanisławem? Początkowy Stanisław Władysław Czelawa jest uosobieniem supremacji Superego, nie jest tą samą osobą, co Władysław Stanisław Czelawa, ponieważ Władysław Stanisław to osobowość istniejąca dopiero po reintegracji profesora Czelawy ze Stachurem, która ma miejsce w chwili zabicia Stachura.

Wpisanie pary Czelawa-Stachur w tak wyraźny schemat psychiczny jak opozycja Superego i Id wywołuje pokusę jego uzupełnienia o elementy stanowione przez pozostałych bohaterów: narratora i panią Wandę, żonę profesora Czelawy.

Narrator odgrywa w tekście podwójną rolę. Jest jednocześnie figurą opisującą wydarzenia oraz ich bezpośrednim uczestnikiem, mającym znaczny wpływ na przebieg fabuły. Wypowiada się w pierwszej osobie liczby pojedynczej, w czasie przeszłym, co zbliża typ narracji do zwierzenia, które często pojawia się w nowelach Grabińskiego w sposób bardziej bezpośredni jako fragmenty dzienników lub pamiętników.

Ostatnie dwa akapity przynoszą zmianę narracji. Jest to relacja z przebiegu procesu sądowego i znana już informacja o wydaniu książki (którą pomijam): „W dwa tygodnie po zaszłym wypadku zasiadł na lawie oskarżonych przed sądem w P. prof. dr Wł. St. dwojga imion Czelawa obwiniany o zabójstwo. Po przeprowadzeniu śledztwa i przesłuchaniu świadków uwolniono podsądnego 23 głosami przeciw 3 od winy i kary" (N, s. 265). Wyraźne jest zarzucenie formy pierwszoosobowej. Lapidarny styl wypowiedzi nasuwa skojarzenia z notatką prasową $a^{34}$. Nie ma tu śladu „ja” narratora. Ten nieprzypadkowy zabieg podsuwa trop istotny przy ustalaniu specyficznej funkcji przez niego pełnionej.

Narrator jest bezimienny. Przedstawia się Stachurowi jako Kazimierz Dzierzba, ale szybko wyjaśnia: „zmyśliłem naprędce” (N, s. 248). Jest młodym, początkującym neurologiem, który kiedyś, w czasie studiów, uczęszczał na wykłady profesora Czelawy, mieszka też przypadkowo w tym samym co on budynku. W proponowanym tu odczytaniu Problematu Czelawy, jako ilustracji swoistej psychomachii, narrator pełniłby funkcję $E g o^{35}$. To właśnie

33 Pełne imiona Czelawy, w takim właśnie szyku, wymienia narrator na s. 239.

34 Ostatnia wypowiedź narratora pierwszoosobowego brzmi: "I skłoniwszy się, bez słowa odszedłem” (N, s. 265). Bardzo podobny zabieg zastosował Grabiński w innej noweli, Saturnin Sektor, gdzie także pierwszoosobowy narrator jest jednym z bohaterów. W ostatnim akapicie tej noweli oznajmia: „Machinalnie wziąłem połyskującą chłodno stal i bez słowa pożegnania odszedłem" (N, s. 276). Tu następuje zmiana narracji i o przebiegu późniejszych wydarzeń czytelnik dowiaduje się już z cytowanych fragmentów dzienników oraz przytaczania stanowiska "opinii publicznej".

${ }^{35}$ Następuje tu ważne rozróżnienie: Czelawa u o s a b i a Superego, a Stachur u o s a b i a ld, tymczasem narrator jedynie $\mathrm{p}$ e ł $\mathrm{n}$ i $\mathrm{fun} \mathrm{k} \mathrm{cj}$ ę Ego. 


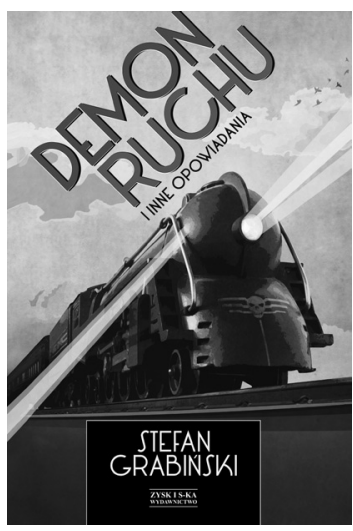

S. Grabiński, Demon ruchu i inne opowiadania, Zysk iS-ka Wydawnictwo, Poznań

on łączy Superego i Id: jest mediatorem między nimi, doprowadza do ich ostatecznej konfrontacji i w pewnej mierze ma też wpływ na jej przebieg.

W finale opowiadania następuje konfrontacja Stachura z Czelawą. Ponieważ spotkanie takie możliwe jest tylko wtedy, gdy jeden z braci jest nieprzytomny - rozwiązanie tytułowego problematu należy do narratora. Ten, wiedząc, że Stachur chce zabić Czelawę, udaje jego sojusznika, by w decydującym momencie przeszkodzić w morderstwie. Paradoksalnie, przetrzymując Stachura do chwili przebudzenia Czelawy, narrator doprowadza do odwrotnego morderstwa: profesor zabija zbira.

Widząc niespokojne zachowanie Stachura, zdając sobie sprawę z sytuacji, narrator w zasadzie podejmuje decyzję co do tego, która ze stron konfliktu ma wyjść z niego zwycięsko. Sam, choć uzbrojony, nie pociąga za spust, jednak doprowadza do ostatecznego rozwiązania. Dlaczego staje po stronie Superego? Mimo iż pełniąc funkcję Ego, nie jest wolny od wpływów Id, kieruje się zasadą rzeczywistości wykluczającą absolutną dominację Id. Dlatego jako lekarz, człowiek z wykształceniem i autorytetem, musi stanąć po stronie Czelawy, choć nie jest wolny od sympatii względem Stachura.

Istnieje jeszcze co najmniej jedno odczytanie intencji narratora. Aby je wypracować, należy przyjrzeć się roli ostatniego z bohaterów opowiadania - pani Wandy.

W swoim studium młodopolskich konstrukcji sobowtórowych Maria Podraza-Kwiatkowska wspomina o roli „kobiety jako przyczynie katastrofy”36. Wzmianka ta, choć poczyniona na marginesie zasadniczego tekstu, wydaje się niezwykle trafna. Kobieta jest przyczyną katastrofy nie tylko w większości „sobowtórowych” opowiadań Grabińskiego ${ }^{37}$, ale również w najbardziej znanych powieściach tego typu, jak Frankenstein Mary Shelley ${ }^{38}$, oraz w wielu opowiadaniach Ernsta Theodora Amadeusa Hoffmana.

W Problemacie Czelawy pani Wanda odgrywa rolę katalizatora ${ }^{39}$, za sprawą którego napięcie pomiędzy Superego a Id staje się nieznośnie intensywne i przemienia się w konflikt. Równolegle pani Wanda jest osobą, przez którą zawiązana zostaje akcja opowiadania: to właśnie ona zjawia się na początku w gabinecie narratora, wciągając go w sprawę tożsamości Stachura branego pierwotnie za własne omamy ${ }^{40}$. Przez większą część opowiadania stanowi cenne źródło informacji o nawykach i poczynaniach swojego męża.

\footnotetext{
${ }^{36}$ M. Podraza-Kwiatkowska, op. cit., s. 111.

37 Poza omawianym tu przykładem podobną sytuację mamy w nowelach Przypadek, Na tropie, Świadek Materna, W willi nad morzem, Engramy Szatery.

${ }^{38}$ Mimo braku fizycznego podobieństwa pomiędzy doktorem Frankensteinem a jego tworem układ ten przyjęło się uważać za sobowtóry: „Potwór jest lustrzanym odbiciem, projekcją twórczych pragnień swojego «ojca». Jest partnerem miłości i nienawiści, prześladowczym demonem, a zarazem sobowtórem doktora" (K. Szczuka, Kopciuszek, Frankenstein i inne, Kraków 2001, s. 173). Zob.: M. Szargot, Sobowtór - romantyczna obsesja (o "Frankensteinie" Mary Shelley), [w:] Tożsamość i rozdwojenie, red. L. Wiśniewska, Bydgoszcz 2002, s. 127-137.

${ }_{39}$ W nowelistyce Grabińskiego zwielokrotnieniu ulegają w zasadzie tylko mężczyźni. Jedyny wyjątek stanowi $W$ domu Sary, ale i w nim tytułowa wampirzyca jest raczej odbiciem swych kochanków-ofiar. Obserwacja ta staje się zajmująca w zestawieniu z tezą G. Pankow, że "heautoskopię należy rozumieć jako imaginatywną metasymbolizację symbolicznej kompetencji człowieka. Sobowtór stanowi halucynacyjny wyraz podświadomej antropomorfizacji i personifikacji języka, jako semiotycznej sfery Innego" (T. Sikora, Euoi. Studia z symbolizmu i metaforyzacji katoptrycznej, Kraków 2004, s. 279-280). W swoich rozważaniach Pankow odwołuje się do Lacana, w opinii którego język ma charakter raczej męski. Pełne wpisanie w porządek symboliczny (uzyskanie pełnej symbolicznej kompetencji) wiąże się z procesem symbolicznej kastracji, a ta, zdaniem Lacana, dostępna jest jedynie mężczyznom. To w pewien sposób tłumaczy nie tylko brak kobiecych sobowtórów u Grabińskiego, ale ogólnie ubóstwo żeńskiej tożsamości katoptrycznej w kulturze.

${ }^{40}$ Taka identyfikacja również wydaje się znacząca. Jeśli traktować sobowtóra jako powrót wypartego, to z punktu widzenia pani Wandy sobowtór jej męża - o wyraźnie erotyczno-agresywnym charakterze - jest jej fantazmatem uosabiającym wyparte przez nią pragnienia i potrzeby seksualne.
} 
Odkrycie istnienia Stachura wprowadza zamieszanie w związek Wandy i jej partnera. Zachodzi tu skomplikowany proces triangulacji, to znaczy pojawienia się $\mathrm{w}$ relacji (małżeńskiej) osoby trzeciej ${ }^{41}$. Staje się ona symbolicznym spełnieniem (obietnicą spełnienia) wszelkich aspektów partnerstwa, w jakich nie sprawdza się mąż. Dlatego seksualnie oziębły Czelawa czuje się zagrożony. Sytuacja ta znajduje odbicie w poczynaniach pani Wandy: przestaje ona sypiać z mężem, przenosi się na noc z sypialni do innego pomieszczenia ${ }^{42}$.

Stachur, traktowany jako internalizacja treści wypartych przez Czelawę, w sposób oczywisty odczuwa silny pociąg względem jego żony. Fakt pożądania (choć ma ono inny, odpowiedni do predyspozycji charakter) tej samej kobiety zaognia konflikt między braćmi. Wydaje się przy tym, że Stachur naśladuje Czelawę, ponieważ prowadząc nocne życie, nie narzekał na brak kobiet. Pragnie Wandy nie dlatego, że jest ona kimś niezwykłym, lecz tylko z powodu relacji, jakie łączą ją z Czelawą. W ten sposób Stachur naśladuje brata, a jego „pożądanie ma naturę mimetyczna, kopiuje pożądanie wzorcowe i wybiera ten sam obiekt, co wzorzec" ${ }^{\prime 3}$. Brak możliwości wyładowania libidalnego na pożądanym obiekcie prowadzi bezpośrednio do zachowań agresywnych względem tego, co stoi na przeszkodzie - w tej roli występuje oczywiście surowe Superego, czyli profesor Czelawa.

Konflikt między Czelawą i Stachurem, którego przedmiotem jest Wanda, wysuwa się w opowiadaniu na plan pierwszy i odciąga uwagę od delikatnie zarysowanego innego trójkąta. W relacje pomiędzy panią Wandą a jej mężem zostaje przecież wciągnięty także narrator! Nie pozostaje on względem Wandy obojętny, co widać w opisie. Już na samym początku mówi o zjawieniu się „pięknej, dziwnie ujmującej słodyczą wyrazu kobiety” (N, s. 232), później wspomina znów o „młodej, pięknej kobiecie” (N, s. 234), wreszcie podaje dokładniejszy, choć nadal daleki od obiektywizmu opis: „twarz jej była zawsze pogodna, a ciemne fijołowe oczy błyszczały szczęściem [ ... ] i nieraz słyszałem w klatce schodowej jej metaliczny śmiech" (N, s. 235).

Emocjonalne nastawienie narratora, który zdaje sobie sprawę z trudnej sytuacji pani Wandy, może tłumaczyć jego zachowanie w trakcie ostatecznej konfrontacji sobowtórów. Jeśli bowiem rzeczywiście narrator odczuwa pociąg fizyczny do Czelawowej, to uratowanie Czelawy kosztem Stachura pozwala mu zachować dogodną pozycję. O wiele łatwiej byłoby narratorowi ubiegać się o względy Wandy, gdy ta znajdowałaby się u boku często nieobecnego, pochłoniętego pracą i seksualnie oziębłego profesora, niż gdyby padła ofiarą Stachura. W takim układzie narrator nie dążyłby do rozwiązania trójkąta, lecz do zajęcia w nim miejsca Stachura, występując jako jego złagodzona wersja. Taka zamiana nie może jednak zajść, ponieważ pozbycie się sobowtóra okazuje się reintegracją osobowości Czelawy, w jego relacji z żoną nie ma dłużej „pustego miejsca”, które miałoby zostać zapełnione przez osobę trzecią.

${ }^{41}$ Znakomity opis zjawiska triangulacji daje Otto F. Kernberg, Zwiq̨zki miłosne. Norma i patologia, tłum. E. Lipska, Poznań 1998, s. 110-112: „w łóżku zawsze znajduje się sześć osób” - czyli para, ich edypalni rywale oraz wyidealizowane obiekty płci przeciwnej - „[j]eżeli silna patologia narcystyczna jednego lub obu partnerów wyklucza zdolność do odczuwania normalnej zazdrości" - a tak byłoby w wypadku superegotycznego Czelawy - „zdolność, która powoduje oczy wistą tolerancję edypalnego rywala - łatwo może dojść do powstania triangulacji".

${ }^{42}$ Oczywiście czyni tak z obawy przed Stachurem, niemniej na planie symbolicznym ważniejsze jest, że z jego powodu przestała sypiać z mężem, a nie to, w jaki sposób sytuacja ta - czy to przez panią Wandę, czy w narracji - jest racjonalizowana.

${ }^{43}$ R. Girard, op. cit., s. 203.

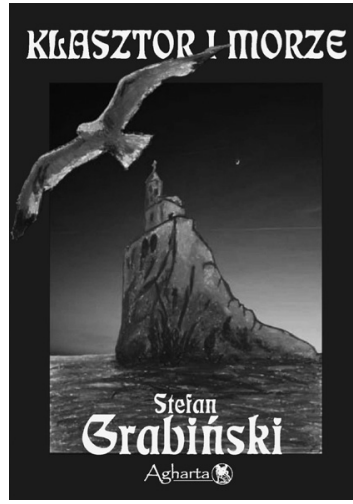

\section{S. Grabiński, Klasztor}

i morze, wstęp i oprac. Jakub Knap, Wydawnictwo Agharta, Kraków 2011

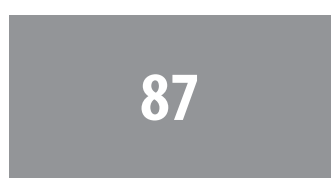


Tożsamość katoptryczna jest z punktu widzenia podmiotu nieznośna. Zdwojenie zagraża tożsamości, staje się niebezpieczne dla struktury „ja”. Dlatego tożsamość katoptryczna dąży do reintegracji. Sobowtór, jako powracające wyparte, musi zostać na powrót uwewnętrzniony, aby podmiot wykształcił tożsamość pełną. W noweli reintegracja odbywa się poprzez zabicie Stachura. Sytuacja ta jest skomplikowana i wymaga uważnej analizy.

Kiedy narrator powstrzymał Stachura przed uduszeniem śpiącego Czelawy, wystarczyło, że zrobił to do godziny ósmej, o której następowała „zamiana”, to jest budził się jeden z braci, a drugi pogrążał w sennym letargu. Będąc świadomym wszystkiego, co zaszło, przebudzony profesor ",jednym skokiem zbliżył się do żony, podjął opuszczony przez nią na podłogę rewolwer i zanim zdołałem przeszkodzić, wypalił do Stachura” (N, s. 264).

Maria Podraza-Kwiatkowska wskazuje na takie rozwiązanie konfliktu z sobowtórem, „kiedy bohater strzelając do niego... zabija siebie. Zakończenie zatem typowe dla utworów sobowtórowych" ${ }^{4}$. W noweli Grabińskiego mamy więc zakończenie mniej typowe, gdyż Czelawa co prawda reaguje na śmiertelną ranę bliźniaka, ale sam pozostaje przy życiu.

To, co zostało $\mathrm{w}$ tekście określone jako działanie reperkusji, w psychoanalizie nosi miano żałobnej identyfikacji. Proces ten polega na internalizowaniu straty, która następnie zostaje zamanifestowana jako częściowe podobieństwo podmiotu do osoby zmarłej. Freud zauważa, że narcystyczne odbicie podmiotu w drugiej osobie sprawia, że w wypadku gdy z jakiegoś powodu zabraknie tej osoby, podmiot zwrócić się może z większą łatwością ku sobie i w ten sposób zrekompensować utratę, odnajdując w sobie samym część straty ${ }^{45}$.

Relacja między Czelawą a Stachurem nacechowana była ambiwalencją, kochali się nie tylko jak bracia, ale głównie jako swoje narcystyczne odbicia, zarazem nienawidząc się ze względu na poczucie zagrożenia oraz utraty pewnej części siebie. Wydaje się, że postawa taka przypomina to, co Julia Kristeva określa mianem „stanów depresyjnych wobec obiektu żałoby" ${ }^{\prime \prime 6}$. Działanie żałoby jeszcze za życia obu braci uzasadnione jest tym, że letarg, w który naprzemiennie zapadają, do złudzenia przypomina śmierć.

Żałobna identyfikacja może objawiać się na różnych płaszczyznach, od fizycznego upodobnienia, przez stany chorobowe, aż po zmiany o charakterze psychicznym. Czerwona plama na czole Czelawy - w miejscu, w którym kula trafila brata - stanowi widzialny aspekt jego zinternalizowania, co należy odczytać jako element reintegracji profesora i Stachura.

Opowiadanie dostarcza zadziwiająco mało informacji na temat zmian, jakim uległ Czelawa po śmierci sobowtóra. Nie mamy pewności co do tego, czy przestał zapadać w nocny letarg ani też jak ułożyły się jego relacje małżeńskie. Proces żałobnej identyfikacji, choć może być etapem, elementem reintegracji osobowości, sam w sobie wydaje się zbyt słaby, aby doprowadzić ją do końca. Czy możliwe jest zatem, by reintegracja nie miała tu miejsca? Czy nie jest ona tylko fantazmatem, myśleniem życzeniowym, mającym usprawiedliwiać morderstwo? Wszak wiemy, że po śmierci Stachura profesor Czelawa został uniewinniony przez sąd, czyli instancję prawną, pełniącą w organizmie państwowym funkcję na wzór Superego. Także publikacja książki o własnym życiu jest kontynuacją naukowych prac pro-

\footnotetext{
${ }^{44}$ M. Podraza-Kwiatkowska, op. cit., s. 112.

45 S. Freud, Żałoba i melancholia, [w:] idem, Psychologia nieświadomości, tłum. R. Reszke, Warszawa 2007, s. 152.

${ }^{46}$ J. Kristeva, Czarne słońce. Depresja i melancholia, tłum. M. P. Markowski, R. Ryziński, Kraków 2007, s. 13-14.
} 
fesora. Więc czy sytuacja ta nie jest tylko zwycięstwem Superego nad pokonanym Id? Są w tekście pewne przesłanki, które każą przecząco odpowiedzieć na tak postawione pytania.

Jak zostało już wskazane, zaraz po tym, gdy profesor Czelawa zabija Stachura - narrator znika. Znika zupełnie, bo jako postać biorąca udział w akcji („I skłoniwszy się bez słowa wyszedłem", N, s. 265) i jednocześnie jako figura opowiadająca. Tłumaczyć to można faktem, że skoro odgrywał rolę Ego, mediując między Superego i Id, to praca jego została zakończona. Jeżeli nastąpiło zespolenie, zjednoczenie tych elementów, właściwe Ego Czelawy mogło zostać wytworzone, zbędny stał się zewnętrzny ekwiwalent w postaci narratora. Innym argumentem przemawiającym za dokonaną reintegracją jest omówiona już wcześniej zmiana szyku imion: przybranie niejako nowego imienia określającego odpowiednio nowy (integralny) podmiot.

Kolejnym kluczem do rozstrzygnięcia kwestii tego, czy w wypadku Czelawy doszło do polączenia, jest tytul pracy bohatera: The Soul and the body..., co sam autor thumaczy w przypisie jako „Dusza i ciało czyli Historia człowieka o dwóch ciałach. Problemat mojego życia” (N, s. 265). Człowieka - a więc pojedynczej osoby („duszy”) uwięzionej w dwóch cielesnych powłokach. Co ważne, do tekstu załączone zostały „dwie podobizny”, mimo że tytul jednoznacznie wskazuje na pojedynczy podmiot („mojego”, nie „naszego”). Zaraz po strzeleniu do brata, Czelawa zwraca się do żony słowami „[n]ie popełniłem zbrodni: miałem prawo rozporządzać wedle woli tym ciałem". Wypowiedź bohatera zwraca uwage na moralne i etyczne konotacje tożsamości katoptrycznej. Rozbicie na dwie autonomiczne osoby w pewien sposób zwalnia z odpowiedzialności za poczynania sobowtóra ${ }^{47}$. Jeżeli podmiot nie jest w stanie kontrolować swego odbicia lub też jeśli - jak w innych nowelach Grabińskiego - nie jest w stanie kontrolować sam siebie przez cały czas (np. w stanach hipnotycznych, somnambulicznych itp.), to „świadomość, skoro nie obejmuje pełni naszego «ja», traci moc etycznego gwaranta naszych czynów"

Widoczne jest tu wartościowanie „dobrej” świadomości i „złej” podświadomości, przy czym dobro polega na możliwości kontrolowania, jest jakby superegotyczne. Podświadomość nie tylko wymyka się kontroli, ale jednocześnie jest ekspresywna, próbuje zdeterminować działania podmiotu. Dobroczyński zauważa jednak, że ta negatywność ma ludzki wymiar, że da się ją w pewien sposób ograniczać poprzez - co ważne w wypadku relacji Czelawy i Stachura - reintegrację, przepracowanie treści wypartych: „[Z]ło, które wyrządzała ona [tj. nieświadomość] jednostce, zdawało się skrojone na ludzką miarę - można je było mniej lub bardziej skutecznie diagnozować, a w sprzyjających warunkach terapeutycznych, poprzez syntezę osobowości wtórnych z pierwotną, zupełnie neutralizować" ${ }^{49}$. Początkowo amoralność odbitej tożsamości jest źródłem niepokojów podmiotu, jednak po zespoleniu się z sobowtórem podmiot zostaje oczyszczony z win za występki podświadomości, tak jak Czelawa zostaje uniewinniony przez sąd w zakończeniu powieści. Tak oto nasuwa się nieodparcie najważniejszy argument przemawiający za dokonaną integracją.

W momencie, w którym tytułowy bohater strzela do Stachura, zabija zewnętrzne, spersonifikowane Id. Jednocześnie jednak popełnia morderstwo, czyn bestialski, antyspołeczny, niegodny. Występuje poza surowe zasady Superego. Uśmiercając Id, Czelawa paradoksalnie

47 J. Sosnowski, Z genealogii doktora Jekylla, [w:] idem, Śmierć czarownicy! Szkice o literaturze i wątpieniu, Warszawa 1993, s. 47.

48 Ibidem.

49 B. Dobroczyński, op. cit., s. 87.

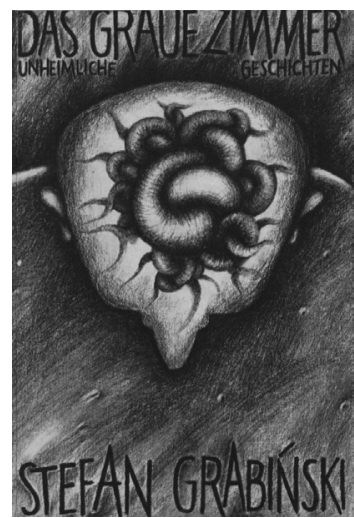

\section{S. Grabiński, Das graue Zimmer: unheimliche} Geschichten, Volk und Welt, Berlin 1985 ("1987) 
budzi Id w sobie. Zatraca się główna różnica dzieląca braci, integrują się poprzez przemoc. Dzieje się tak dlatego, że przemoc niweluje różnice, ale również z powodu pierwotnej tożsamości, ukrytej identyczności sobowtórów. Stan walki powoduje pewien powrót, regres do momentu przed rozróżnieniem. Mechanizm ten jednoznacznie wskazuje, iż dokonuje się finalna reintegracja. Ma ona jednak pesymistyczną wymowę: pełnia tożsamości możliwa jest do osiągnięcia jedynie poprzez akceptację swej złej, zbrodniczej natury.

Być może swego rodzaju nauką płynącą z opowiadania Grabińskiego jest nie tyle prawda o mrocznej, zbrodniczej części naszego Ja, ile ostrzeżenie o niebezpieczeństwach związanych z całkowitym wyparciem tej części. Wracając do przytoczonej już rozprawy Sosnowskiego, warto podkreślić, że „to stłumienie, nie zaś uwolnienie czy rozwydrzenie mrocznych instynktów nadało im niszczącą moc"so.

\section{Komuni(kacj)a}

Zjawisko katoptryzmu w literaturze nie ogranicza się jedynie do konstrukcji sobowtórowych oraz zwielokrotnienia jaźni. Dotyczy również obszaru rozważań o sztuce, a ściślej rzecz biorąc: relacji pomiędzy artystą a jego dziełem. Ponieważ podmiot twórczy „jako artysta jest swym dziełem, a nie człowiekiem. Każdy twórczy człowiek jest dwójnią czy też syntezą paradoksalnych właściwości. Z jednej strony jest on człowiekiem i osobą, z drugiej jednak bezosobowym ludzkim procesem"51.

Problem ten, zawsze obecny w refleksji nad sztuką, stał się szczególnie ważny w dobie modernizmu. W charakterystyczny dla tego okresu sposób został ujęty w zderzeniu dwóch ambiwalentnych względem siebie postaw: twórcy kreatora i twórcy medium ${ }^{52}$.

Ponieważ wiedziano, że człowiek nie w pełni jest świadomy, że są sfery ludzkiej psychiki niemożliwe do uchwycenia przez podmiot w prosty sposób, zaczęto zadawać pytanie: jak wiele z tych tajemniczych pokładów znajdzie swój wyraz w sztuce? Mnogość udzielanych odpowiedzi prowadziła paradoksalnie do postawienia nowego, bardziej podstawowego pytania, pytania o tożsamość twórcy. Jeśli bowiem artysta był tylko pośrednikiem pomiędzy nieświadomością a jej wyrazem w postaci dzieła sztuki, to jaki był udział jego Ego w procesie kreacji? Czy na bazie tego udziału mógł on budować swą artystyczną tożsamość? I druga, równie dramatyczna kwestia - jeśli to nie podświadomość podmiotu przezeń przemawia, a tylko kultura, to jak wtedy może ukonstytuować się podmiot? W skrócie: co jest istotą świadomości podmiotu, skoro $\mathrm{z}$ jednej strony jest on marionetką $\mathrm{w}$ rękach podświadomości, a z drugiej wytworem coraz bardziej masowej kultury?

Podwójna walka - o tożsamość oraz indywidualność - pozwala wpisać motyw artystycznej kreacji w krąg zagadnień katoptrycznych. Charakterystyczna dlań dążność do reintegracji stanie się w obrębie sztuki próbą odzyskania artystycznej tożsamości podmiotu, próbą - trzeba podkreślić - nie zawsze udaną.

Nowelą, która w całości traktuje o problemach artystycznego wyrazu, jest Dziedzina. Opowiada ona historię Wrześmiana, młodego poety, który po wydaniu czwartego tomu

\footnotetext{
50 J. Sosnowski, op. cit., s. 51.

51 C. G. Jung, Archetypy i symbole. Pisma wybrane, tłum. J. Prokopiuk, Warszawa 1976, s. 398.

52 W. Gutowski, Kreator i medium. Wokół problemu tożsamości artysty, "Pamiętnik Literacki” 1982, z. 3/4.
} 
wierszy nagle odsunął się od życia towarzyskiego, by przez kilkanaście lat, zamieszkawszy samotnie na przedmieściach, szukać nowych, silniejszych środków ekspresji. Ponieważ wycofanie się ze społeczeństwa, będące aktem skrajnego indywidualizmu, jest z punktu widzenia społeczeństwa niekorzystne, a nawet niebezpieczne, bo podważa w pewien sposób jego struktury (i ich konieczność względem jednostki), toteż opinia publiczna musiała w jakiś sposób zracjonalizować milczenie poety. Początkowo spodziewano się intensywnej pracy nad nowym dziełem, lecz brak efektów skłonił krytyków do uznania, że Wrześmian jako artysta „wyczerpał się przedwcześnie”, „wypowiedział się za szybko”, co z kolei tłumaczono tym, iż „zbyt wiele zagadnień naraz poruszał w jednej kreacji” (N, s. 279).

Ale to nie krytyka literacka, ani też nie recepcja utworów Wrześmiana sprawiła, że nagle zniknął. Zniknięcie miało zresztą podwójny charakter. Przejawiło się milczeniem w sensie zaprzestania publikacji oraz wyobcowaniem ze społeczeństwa, przeprowadzką w odludną okolicę, zerwaniem więzi ze znajomymi. Powodem wyalienowania były poszukiwania nowego środka ekspresji artystycznej. Pragnienie Wrześmiana było „najwyższą realizacją bez reszty, wypowiedzeniem się pełnym, bez cienia niedoborów” (N, s. 282). Literatura, poprzez którą to pragnienie starał się zaspokoić, zawiodła go. Okazała się pełna reguł, prądów i mód. Gdy udało się Wrześmianowi wspiąć ponad nie, napotkał na ostatnią przeszkodę, której pokonać nie mógł. Przeszkodą tą okazał się język, sama materia, bez której dzieło literackie nie może zaistnieć.

Język dokonuje mediacji między myślą a rzeczywistością, warunkuje sposób, w jaki podmiot odbiera (interpretuje) świat. Jest też sposobem wyrażania myśli w świecie. Reprezentuje treści myślowe podmiotu. Jednakże reprezentujący charakter języka zakłada nieobecność tego, co opisuje ${ }^{53}$. Nic nie może być obecne w języku - poza samym językiem. Dlatego bohater początkowo, co prawda, stara się wyeksploatować materiał językowy tak, by dostroić go maksymalnie do swoich myśli, ostatecznie jednak ponosi porażkę i postanawia zrezygnować z języka.

Zapośredniczenie $\mathrm{w}$ języku uniemożliwia pełnię wypowiedzenia. Język nie stanowi przecież elementu podmiotu, a jako pryzmat w procesie wypowiadania daje obraz zniekształcony. „Jeśli bowiem język jest zawsze językiem Innego, który podmiot deformuje, dezintegruje lub ubezwłasnowolnia” - uważa Ryszard Nycz - „to prawdziwa wolność, a także autentyczność i całkowitość wyrazu mogą być dostępne jedynie poza językiem" ${ }^{\text {"4 }}$. I właśnie poza językiem swą wolność wyrazu chciał odnaleźć Wrześmian. Droga do wolności wiodła go poprzez zaniechanie działalności literackiej, ale także poprzez osamotnienie. Język jest bowiem tworem społecznym, służy do porozumiewania się, komunikacji. Stąd prosty wniosek: ucieczka przed językiem musi być jednocześnie ucieczką przed społeczeństwem.

Efektem postrzegania języka jako „źródła problemów w sferze poznania, komunikacji, ekspresji” ${ }^{55}$ jest poddanie się temu „narzędziu wyobcowania”. Bo jeśli język wyobcowuje podmiot względem przedmiotu, to brak języka, jego odrzucenie, będzie wyobcowaniem podmiotu względem Innego ${ }^{56}$. Skoro nic nie mówię, to - w psychoanalitycznym odczy-

53 Zob. M. P. Markowski, O reprezentacji, [w:] Kulturowa teoria literatury. Główne pojęcia i problemy, red. M. P. Markowski, R. Nycz, Kraków 2006, s. 287-333.

54 R. Nycz, Język modernizmu. Prolegomena historycznoliterackie, Wrocław 1997, s. 104.

55 Ibidem, s. 63.

56 Podmiot, nie mogąc wypowiedzieć się w sposób bezpośredni, zawsze ucieka się do zapośredniczenia w języku. Reprezentacja językowa, jaka ma wtedy miejsce, równoznaczna jest z brakiem obiektu w wypowiedzi. Przez to podmiot zostaje względem obiektu wyobcowany. Gdy zaś podmiot milczy, nie tworzy swojej 

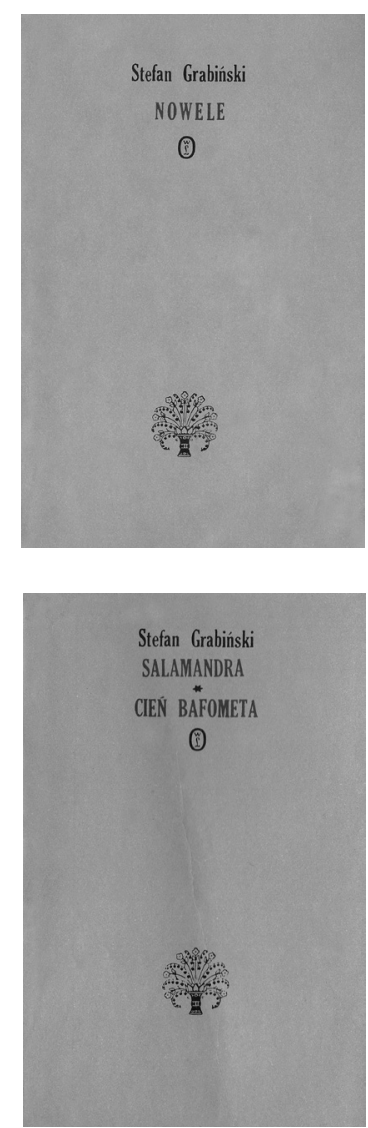

taniu - nie istnieję, jestem martwy, gdyż nie posiadam żadnej symbolicznej reprezentacji. Wyrażenie siebie przez formę niezakotwiczoną w kulturze, wybicie się ponad kolektywny język, jest aktem dalece posuniętego indywidualizmu i ma charakter typowo egotyczny. W centrum pragnienia podmiotu znajduje się przecież on sam, dąży do eksternalizacji samego siebie - co po raz kolejny bezpośrednio nawiązuje do katoptrycznego podwojenia.

Tomasz Sikora łączy ze sobą narcystyczną fiksację z odrzuceniem mowy: „[L]ibidalne nadobsadzenie archaicznego obrazu siebie wyraża się we wrogości, zarozumiałości, sarkazmie i m i l c z e n i u [podkr. - K. G.], które należy rozumieć jako mechanizmy obronne, służące jego utrzymaniu i obronie" ${ }^{\text {"5 }}$. W następnym zdaniu Sikora przytacza tezę, która zapowiada dalsze, tragiczne losy Wrześmiana: „ten stan rzeczy może prowadzić do regresji głębszej, niż prymarny narcyzm, do doznań, których charakterystyka przypomina doświadczenie rozczłonkowanego ciała sprzed fazy zwierciadła opisywanej przez Lacana" ${ }^{58}$. Skupienie się na sobie samym, chęć wyrażenia siebie prowadzi paradoksalnie do milczenia, a to ostatecznie przywołuje pokawałkowanie ciała sprzed fazy symbolicznej. Należy przy tym mieć na uwadze, że proces ten ma charakter r e g r e s y w n y, to znaczy kolejne fazy następują po sobie w porządku odwróconym względem tego, jaki występuje u normalnie rozwijającego się człowieka.

Tryumf indywidualizmu domaga się afirmacji. Nie może ona nastąpić ze strony społeczeństwa, bo wtedy indywidualizm musiałby wyrazić się w nieindywidualnym języku - co sprzeczne jest z jego istotą. Potrzeba Innego prowadzi do obsadzenia w jego funkcji rozmaitych konstrukcji. To właśnie ten mechanizm nadaje sens różnego rodzaju zakonom zamkniętym: wywołują one wśród zakonników pragnienie obcowania z Innym, który ze względu na kulturowe uwarunkowania zostaje automatycznie obsadzony fantazmatem Boga. Podobnie rzecz ma się z pustelnikami. A przecież Wrześmian jest jakby pustelnikiem: odizolowany od ludzi, żyjący w swojej samotni, przyjąwszy śluby milczenia, oddaje się kontemplacji swojego absolutu: Sztuki.

Sztuka sama w sobie wydaje się jednak czymś zbyt abstrakcyjnym, by zająć miejsce Innego. Musi zostać ona wcześniej zantroponimizowana. Jak zauważa René Girard, „[m]onstrualny sobowtór pojawia się tam, gdzie na poprzednich etapach znajdowali się «Inny» oraz «Ja», zawsze oddzieleni oscylującą różnicą" ${ }^{\text {" } 9}$. Stąd nagle ludzkie fantomy w sąsiedztwie Wrześmiana.

Męska postać widziana w oknie kamienicy, po której pojawiają się kolejne, jest oczywiście artystyczną projekcją bohatera. W ten sposób pozycja symbolicznego Innego zostaje obsadzona przez konstrukcję będącą zarazem dziełem sztuki oraz sposobem wyrażenia „myśli jego [tj. Wrześmiana - K. G.] możliwie najwierniej” (N, s. 282). Poprzez sztukę wyraża się podmiot. Samotność wywołuje twory sobowtórowe, te zaś pogłębiają samotność. Dzieje się tak, ponieważ podmiot odbija się w Innym, który w rzeczywistości nie jest Innym tylko projekcją podmiotu podstawioną w miejsce Innego. Podmiot zostaje uwięziony pomiędzy dwoma zwierciadłami odbijającymi siebie w nieskończonym ciągu powtórzeń, tworząc katoptryczny dramat.

symbolicznej tożsamości z komponentów wpisanych w język, przez co nie może zostać zauważony przez symbolicznego Innego. Być może jest tak, że w konsekwencji wyobcowania zarówno względem przedmiotu, jak i Innego podmiot ostatecznie wyobcowuje się względem samego siebie, tj. własnej podmiotowości.

57 T. Sikora, op. cit., s. 261.

58 Ibidem.

59 R. Girard, op. cit., s. 226. 
Grabiński cel oryginalnego ujmowania rzeczywistości w literaturze rozumiał jako „zgłębianie istoty bytu, rozszerzenie sfery myśli i uczuć naszych w stosunku do niego, przybliżenie momentu rozwiązania wielkiej zagadki. Więc walka o zdobycie Nieznanego, namiętna, prometeiczna żądza wydarcia mu tajemnicy; walka-rozwój, spotęgowanie pulsacji energii duchowej i skrzydlata gonitwa w nieskończoność" ${ }^{60}$. Ten coraz bardziej poetycki w wyrazie opis wskazuje na silnie transgresyjny charakter odbioru literatury oraz - przede wszystkim - jej stwarzania. Proces twórczy jest działaniem ontologicznym, które dociera do przyczyny bytu, odkrywa, dlaczego rzeczy jawią się takimi, a nie innymi. Od poznania tych mechanizmów do użycia ich - tylko jeden krok. Jeśli Grabiński nie może go dokonać, to z pewnością zdolny do tego jest Wrześmian.

Nie należy mylić tego z działalnością propagandową. Literatura Wrześmiana, dziwna i niepokojąca, nie jest zaangażowana. Obca jest mu pozytywistyczna idea pracy u podstaw, idea literatury poruszającej ważne kwestie społeczne, zwracającej uwagę na socjalne problemy. Podobnie romantyczne ideały literatury nawołującej do czynu, wzbudzającej wzniosłe uczucia, poczucie obowiązku - nie są tym, co wpisane zostało w utwory artysty. Sposób oddziaływania literatury na rzeczywistość jest tu dużo bardziej bezpośredni, ma charakter magiczny.

Magia, będąca sposobem oddziaływania na rzeczywistośćc ${ }^{61}$, w pewien sposób zbliża się do literatury. Obie te dziedziny ludzkiej działalności zajmują się opisywaniem i modyfikowaniem świata. Opisywanie rzeczywistości jest o tyle działaniem na niej, o ile ludzki umysł działa wybiórczo. Świadomość nie jest w stanie rejestrować wszystkich elementów i sygnałów płynących z otoczenia, percepcja nakłada pewien filtr na postrzegany obraz ${ }^{62}$. Opis dostarczać może sygnałów, które w percepcji codzienności były przez czytelnika pomijane. To prowadzi do modyfikacji jego oglądu świata, a więc świata w ujęciu subiektywnym, i w tym znaczeniu jest operacją magiczną, jako że „magija jest Nauką zrozumienia siebie i swojego otoczenia" ${ }^{\prime 3}$.

Wrześmian nie jest zadowolony z takiego tylko oddziaływania. Nie chce zmieniać rzeczywistości poprzez wpływ na jej ogląd. Jego ambicją jest kreacja rzeczywistości. Tego typu działanie znosi mediację, która w wypadku modyfikowania percepcji przedstawia się w schemacie: artysta - tekst (opis) - czytelnik - tekst (świat, rzeczywistość). Ogranicza go do dwóch tylko elementów: artysta - rzeczywistość.

Wykluczenie odbiorcy sprawia, że znak ( $w$ wypadku Wrześmiana będzie to myśl niezakotwiczona $\mathrm{w}$ języku) nie ulega transformacji w procesie percepcji. Z drugiej strony: trudno mówić o znaku bez powtórzenia. Sytuacja przedstawiona w Dziedzinie jest pod tym względem bardzo ciekawa. Mamy tu do czynienia z powtórzeniem na dwóch płasz-

\footnotetext{
60 S. Grabiński, Zagadnienie oryginalności..., s. 1.

${ }^{61}$ Aleister Crowley definiował magię jako „sztukę i naukę powodowania zmian w zgodzie z własną Wolą". Inny teoretyk magii z tego okresu, Austin Osman Spare, określał magię jako "naturalną zdolność do przyciągania pewnych rzeczy bez proszenia o nie" (Księga rozkoszy, tłum. K. Azarewicz, Warszawa 2005, s. 24).

62 Innymi słowy: postrzeganie jest zawsze procesem wyboru i uogólnienia. Składowym elementom (np. ręka, długopis, ruch, litera) nadaje się ujęcie perspektywistyczne (pisanie). Proces ten nie jest zwykle świadomy (choć może być przedmiotem świadomej refleksji) i zostaje zdeterminowany przez różne czynniki, indywidualne (doświadczenia, ambicje, marzenia) i społeczne (język, dyskurs, prawo). Samo wychwytywanie (tworzenie) sensu spośród zbioru zgoła bezsensownych elementów składowych możemy określić jako odczytanie, podobnie jak odczytanie zdania polega na wychwytywaniu sensu ze zbioru bezsensownych liter. Tak szerokie rozumienie tekstu sprawia, że każda modyfikacja rzeczywistości opiera się właśnie na działaniu na tekście, ergo jest operacją literacką.

${ }^{63}$ A. Crowley, Magija w teorii i praktyce, tłum. M. Uniejski, Katowice 1998, s. 19.
}

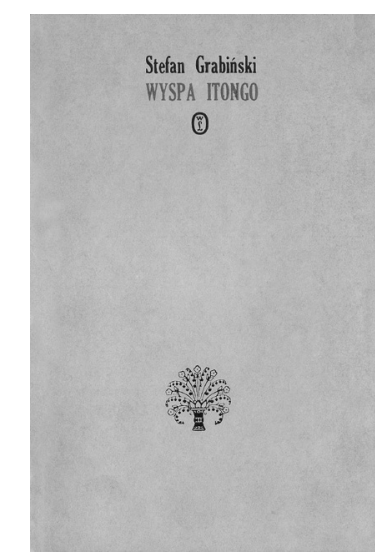

\section{S. Grabiński, Utwory}

wybrane, wyb., wstęp i komentarz Artur Hutnikiewicz, t. 1-3, Wydawnictwo Literackie, Kraków 1980

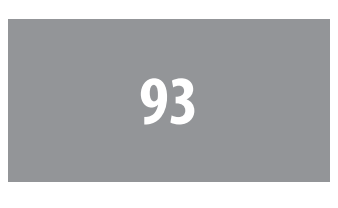


czyznach. Pierwsza - to powtórzenie samego wytworu. Jeśli widmowe postaci traktować jako wyrazy myśli Wrześmiana (lub, o czym więcej w dalszej części, jego podmiotowości), to ich powielenie nadaje im charakter znaku w sensie Derridiańskiego Abbilden, „odbijającej, reproduktywnej, powtórzeniowej natury wyrazu” ${ }^{\prime 4}$. W ten sposób wytłumaczyć można mnogość zjaw: „Lecz kiedy już mrok wchodził w tajne zmowy z nocą, wykwitła w trzecim $\mathrm{z}$ rzędu oknie nowa postać, by nie ustąpić aż do rana. Tak w przeciągu paru dni zapełniły się wszystkie okna willi złowieszczymi twarzami” (N, s. 287). Repetycja ustanawia znaczące. Pojawia się jednak problem drugiej strony znaku, jego Einbilden, natury transformującej, obalającej mit bezpośredniej komunikacji, ale jednak niewyzbywalnej.

Wcześniej wskazałem na dwuelementowy schemat oddziaływania magicznego, uwzględniający tylko artystę oddziałującego i rzeczywistość, na którą się oddziałuje. Jest to też w pewnym sensie schemat komunikacji o tyle, o ile zmiana ta niesie w sobie jakąś treść. Ustanowienie nowej rzeczywistości będzie wypowiedzeniem tej treści o charakterze performatywnym. Ale jako akt komunikacji, w którym autor będzie nadawcą, a rzeczywistość (jej nowy element) treścią, musi zostać poszerzony o jeszcze jeden element: o odbiorcę. Kto jest odbiorcą komunikatu? Ten, który widzi zjawy - Wrześmian. Dlatego oba schematy odzwierciedlają sytuację z opowiadania, mimo pozornie różnej liczby elementów. Bohater stanowi bowiem jednocześnie nadawcę i odbiorcę swego komunikatu.

To zwielokrotnienie artysty jest drugim ze wspomnianych powtórzeń, które umożliwia zaistnienie znaku. Jeżeli za Deleuzem przyjmiemy, iż każde powtórzenie implikuje pewną różnicę ${ }^{65}$, to Wrześmian nadawca oraz Wrześmian odbiorca różnią się od siebie, choćby przez fakt uzewnętrznienia swoich myśli w formie zjaw (nadawca dopiero to robi, odbiorca już to zrobil). A zatem teoretycznie odmienne jest postrzeganie fantomów przez te dwie (różne) osoby, co umożliwia dopełnienie znaku przez jego transformacyjną naturę Einbilden.

Poprzez znakową naturę swoich projekcji Wrześmian staje się zwielokrotniony, podwojony w funkcji nadawcy-odbiorcy. Zjawy stają się jak lustro, przez które zostaje odbity, lecz odbicie to nie grzęźnie w lustrze, ale wraca z powrotem do Wrześmiana, wywołując zdwojenie w jego tożsamości. Zdwojenie katoptryczne.

Po długotrwałym wpatrywaniu się w willę mieszczącą się po drugiej stronie ulicy, naprzeciw wynajmowanego mieszkania, myśli bohatera zaczęły nabierać ludzkiego kształtu. Co noc w oknach budynku pojawiały się coraz to nowe zjawy, aż w końcu wypełnity cały budynek. Było to spełnienie Wrześmianowych pragnień. Tworzenie bez pośrednictwa pisma, z samych tylko myśli. Artur Hutnikiewicz streszcza historię tej idei:

Koncepcja partenogenezy, dzieworództwa myśli, stwarzającej nową rzeczywistość widzialną, nie była bynajmniej obca filozofii dawnej i nowszej. Z niej przecie począł się jeden z zasadniczych nurtów myśli ludzkiej: filozoficzny idealizm. Ona tkwiła u podstaw tak bliskiego Grabińskiemu platonizmu, który w ideach widział prawzór świata materii. Rozwijał szerzej tę koncepcję Filon aleksandryjski w swojej nauce o Logosie, uosobieniu kształtującej rzeczywistość myśli i energii boskiej. Paracelsus, którego Grabiński nazywał jednym „z najgłębszych magów w Europie”, podejmował identyczną koncepcję [... . W dobie romantyzmu to samo będzie mó-

64 J. Derrida, Forma i znaczenie. Uwagi o fenomenologii języka, [w:] idem, Pismo filozofii, tłum. B. Banasiak, Kraków 1993, s. 143.

65 G. Deleuze, Powtórzenie i różnica, [w:] idem, Różnica i powtórzenie, tłum. B. Banasiak, K. Matuszewski, Warszawa 1997. 
wić Fichte, gdy uzna pierwszość myśli jako jedynej stwórczej praprzyczyny istnienia i uczyni ją zasadą swej idealistycznej metafizyki. Pod urokiem zaś jego pomysłów formułował swe zasadnicze idee romantyczny idealizm magiczny wierzący w możliwość tak potężnego zdynamizowania energii duchowej w człowieku, że będzie on mógł myślą nad naturą całą panować i realizować bezwzględnie swoją wolę [TLSG, s. 131].

W takim kontekście Hutnikiewicz odczytuje Dziedzinę jako „fantastyczną baśń [...] o mocy, co równa boskiej pozwalałaby aktem myśli stwarzać całe światy" ${ }^{16}$. Byłoby to wtedy opowiadanie typowo romantyczne. Tymczasem nowoczesność krytyczna odchodzi od romantycznych paradygmatów. Nie chodzi w niej bowiem o kreację wewnątrz obiektywnie istniejącej rzeczywistości, lecz o kreowanie rzeczywistości zawsze subiektywnej. Stąd materialne ujęcie zjaw, fantomów i duchów Grabińskiego - choć jest możliwe i pozwala na spójne odczytanie w spirytualistycznym ujęciu - nie wyczerpuje potencjału jego twórczości, a nawet spłyca ją $\mathrm{i}$ - z dzisiejszej perspektywy - trywializuje.

Problemem, na jaki trafia odczytanie Hutnikiewicza, jest modernistyczne przedstawienie szeroko rozumianych nauk tajemnych. Badacz, pisząc o „odczytaniu w spirytualistycznym ujęciu”, wydaje się mieć na myśli zjawiska bliższe pozytywizmowi. Rozczarowanie nauką, która nie potrafiła wyjaśnić wszystkich zjawisk, spowodowało wzmożone zainteresowanie zjawiskami określanymi jako nadnaturalne, paranormalne itp. Ale charakter tego zainteresowania był wciąż pozytywistyczny: starano się prowadzić ich naukowe obserwacje, traktować w ramach eksperymentu. Takie ujęcie typowe będzie dla wcześniejszej, zachowawczej fazy nowoczesności, i w niej zamyka się interpretacja Hutnikiewicza.

Inaczej przedstawia się zagadnienie nauk tajemnych w kontekście nowoczesności zorientowanej krytycznie ${ }^{67}$. Zjawiska nie będą opisywane poprzez paradygmat naukowy, a raczej wyjaśniane przez odniesienie się do indywidualnych projekcji umysłu.

Autorytet świata okultyzmu pierwszej połowy XX wieku wysuwa zastrzeżenie:

W księdze mówi się o sefirotach i ścieżkach, o duchach i zaklęciach, o bogach, sferach, planach i wielu innych sprawach, które mogą (albo i nie) istnieć. To c z y is t n i e ją n i e m a z n a c z e n i a. Z wykonaniem pewnych działań wiążą się określone skutki. Uczniów ostrzega się poważnie, aby nie nadawali im filozoficznej wagi ani $\mathrm{n}$ i e $\mathrm{traktowali} \mathrm{i} \mathrm{c} \mathrm{h} \mathrm{jako}$ o b i e k t y w n e j r z e c z y wis toś c i ${ }^{68}$.

Realny status elementów operacji magicznych został zakwestionowany. Jego znaczenie uległo zniesieniu, zostało wyparte przez pragmatyzm („z wykonywaniem pewnych działań wiążą się określone skutki”) ${ }^{69}$.

Rozważania na temat statusu zjaw pojawiających się w oknach willi mają podstawowe znaczenie z punktu widzenia tożsamości katoptrycznej. Otóż u Wrześmiana możemy mówić o odbiciu tożsamości tylko w wypadku, gdy zjaw y te u z namy za e ma $\mathrm{n}$ a c j ę j e g o u m y s $\mathrm{lu}$. W innym razie będą to byty przyzwane przez artystę z innych

66 TLSG, s. 134.

67 Terminów „nowoczesność zachowawcza” i „nowoczesność krytyczna” używam w rozumieniu zaproponowanym przez Michała Pawła Markowskiego, Polska literatura nowoczesna. Leśmian, Schulz, Witkacy, Kraków 2007.

68 A. Crowley, op. cit., s. 341

${ }^{69}$ W innym miejscu Crowley napisze jeszcze dobitniej: „Sukces twym dowodem”. 
wymiarów (bądź w jakikolwiek inny sposób powołane do istnienia), jednak niepowiązane z tożsamością tego, który je wywołuje. Dlatego odczytanie Dziedziny jako dzieła należącego do polskiej literatury nowoczesnej w jej krytycznym ujęciu oraz odczytanie poprzez pryzmat tożsamości katoptrycznej wzajemnie się implikują i uzupełniają.

Projekcje Wrześmiana nie mają przyjaznego charakteru. Już przy pojawieniu się pierwszej zjawy narrator zaznacza: „Wzrok nieznajomego, utkwiony weń nieporuszenie był groźny" (N, s. 287). Podobnie złowrogi charakter będą miały kolejne widma. Groza, szaleństwo, obłęd - to przymioty zjaw. Ale przecież takie same określenia wystąpiły w kontekście wcześniejszych, literackich utworów bohatera. Są one do pewnego stopnia tożsame, stanowią powtórzenie, którego elementem różnicującym jest nie tyle treść, co forma.

Ta tożsamość treści wskazywałaby na pierwotną obecność podmiotu w dziele literackim. Otóż problemem Wrześmiana było nie tylko wyrażenie siebie poprzez język. W tym samym stopniu kłopotliwe było odczytanie tych elementów, które udałoby mu się wyrazić. Wypowiedzenie się jest problematyczne zarówno od strony relacji podmiot-komunikat, jak i komunikat-odbiorca. Usunięcie zapośredniczenia w języku pozwoliło bohaterowi nie tylko na pełniejszą obecność w komunikacie, ale również na pełniejszą zrozumiałość, na maksymalne ograniczenie interpretacji.

Utopia bezpośredniej komunikacji staje się tu utopią jedności trzech tekstów: tekstu autora, tzn. takiego wyrazu podmiotowości, jaki autor chciał zawrzeć w tekście, tekstu-samego-w-sobie oraz tekstu czytelnika, będącego aktualizacją poprzedniego, uwarunkowaną przez odbiorcę. Odbywa się to poprzez eliminację kolejnych elementów komunikatu. Milczenie zniosło barierę języka, co umożliwiło wypowiedź niezapośredniczoną w zniekształcającym kodzie symbolicznym. Samotność pozwoliła na odrzucenie odbiorcy lub też na jego asymilację z autorem, co zapewniło poprawność odczytania, maksymalne zbliżenie intencji autora i odbiorcy. Ostatecznie eliminacji ulegnie sam autor. Stworzone dzieło nabędzie pełnej niezależności.

Pojawienie się widmowych postaci staje się realizacją zamiaru Wrześmiana. A jednak obecność dzieła wywołuje w nim strach. Kiedy dostrzegł pierwszą postać, „zapuścił storę i oświetlił mieszkanie: nie mógł dłużej wytrzymać wzroku” (N, s. 286).

Charakter powołanych do istnienia zjaw, ich groźny, złowieszczy wyraz, można tłumaczyć typowością dzieła Wrześmiana. Tak jak niegdyś utwory literackie, tak teraz jego emanacje mają te same cechy. Nie da się tym jednak wytłumaczyć lęku Wrześmiana. Czy artysta może bać się własnych kreacji? W zasadzie - tak. Jeśli ujmiemy je w kategoriach lustrzanego odbicia, to sytuacja taka jest możliwa. Dochodzi do niej, gdyż artysta odbija się w swoim dziele, ale ponieważ odbija się w nim cały, to znaczy nie tylko skryty za maską tożsamości, ale również wraz z ujawnianymi w procesie tworzenia treściami podświadomymi, wypartymi itp., może wywołać lęk u samego (świadomego) siebie. Można wskazać jeszcze jedno, zgoła odmienne wytłumaczenie lęku Wrześmiana. Chodzi tu o faktyczny przedmiot pragnienia, który nie leży w obiekcie, któremu się tę właściwość przypisuje, lecz w samym tylko dążeniu ku temu obiektowi. Slavoj Žižek, omawiając stanowisko Lacana, tak pisze o tym zjawisku:

[O]draczanie „samej rzeczy” błędnie traktujemy jako „rzecz samą”, poszukiwanie i chwiejność właściwe pragnieniu faktycznie są już realizacją pragnienia. Realizacja pragnienia zatem nie po- 
lega na jego „spełnieniu”, „pełnym zaspokojeniu”, a raczej pokrywa się z powielaniem samego pragnienia jako takiego, z jego kolistym ruchem $^{70}$.

Brak jest konstytutywny dla pragnienia. Nie chcemy czegoś obecnego. Jednocześnie podmiotowość aktualizuje się w pragnieniu (jako „ja” pragnące), oznacza to, że pragnienie będzie kierowane na coraz to nowy obiekt oraz że ostatecznym jego obiektem jest śmierć, która rozwiązuje podmiotowość ${ }^{71}$. Stąd obecny w perspektywie realizacji pragnienia lęk.

Prawdziwym pragnieniem Wrześmiana nie jest więc w y p o wi e d z e n i e, lecz w y p o wi a d a ć s i ę. Jest ono bardziej czasownikiem niż rzeczownikiem, czymś dynamicznym niż statycznym. Bliskość wypowiedzenia inwokuje kres, czyli śmierć, i przez to napawa trwogą. Bohater ma świadomość tej zależności już na początku utworu, przed pojawieniem się zjaw, a nawet przed przeprowadzką na obrzeża miasta:

Lecz Wrześmian rozumial, że taka realizacja mogła stać się dla niego samego zagładą. Bezwzględne spełnienie byłoby też absolutnym wyżyciem się, więc śmiercią z wytężenia, nadmiaru ...

Bo ideał - wszak wiadomo - jest w śmierci; dzieło przytłacza twórcę swym ciężarem; myśli zrealizowane w pełni mogą stać się groźne i mściwe; zwłaszcza myśli obłąkane. Pozostawione sobie, bez punktu oparcia o rzeczywiste podłoże, mogą być niebezpieczne dla tego, który je stworzył [N, s. 282].

Zdając sobie sprawę z konsekwencji swoich działań, bohater nie jest w stanie powstrzymać się przed pełną realizacją pragnienia. Strach, jaki odczuwa, nie doprowadza do zaprzestania kreacji opartej - jak już zostało wyjaśnione - na podwójnym powtórzeniu.

Gdy cały dom zapełnił się zjawami, proces repetycji dobiegł końca. Wyczerpała się reprodukcyjna moc dziedziny, która nie mogła już pomieścić kolejnych powtórzeń. Wtedy bohater wezwany został do środka. Cała droga Wrześmiana do willi obfituje w metaforykę tanatalną: „długie cienie”, „żałobne ściany krzewów”, „kamienne płyty” itd. Przemierzana droga jest aż nazbyt widoczną drogą ku śmierci.

We wnętrzu willi Wrześmian przechodzi przez korytarz pełen korynckich kolumn. Za jego plecami pojawiają się widmowe postaci uniemożliwiające mu odwrót. Wreszcie dociera do okrągłej sali, gdzie zostaje otoczony. Tu toczy się jedyny w opowiadaniu dialog (N, s. 288-289), w którym na plan pierwszy wysuwa się jedna rzecz: każda wypowiedź zjaw zawiera powtórzenie („To on! To on!”, „Krwi! Krwi!”, „Chcemy żyć! Chcemy żyć!”, „Otoczyć! Otoczyć!”, „Udusić go! Udusić!”), tak jakby twory będące powtórzeniem skazane były na repetycje i to repetycje wykrzyczane, gdyż z wyjątkiem jednego pytania retorycznego każde zdanie jest wykrzyknieniem ${ }^{72}$. Wydaje się to potwierdzać wcześniejsze domysły o wyczerpaniu dziedziny, w której brak już miejsca na kolejne powtórzenia: kiedy zjawy mówią „[p]rzykułeś nas, nędzniku, do tego domu! Chcemy wyjść stąd na świat, wyzwolić się od

70 S. Žižek, Patrzqc z ukosa. Do Lacana przez kulturę popularnq, tłum. J. Margański, Warszawa 2003, s. 20.

71 Zob. S. Freud, Poza zasada przyjemności, tłum. J. Prokopiuk, Warszawa 2005.

72 Przywodzi to na myśl echo, które "działa" także o tyle, o ile wypowiedź zostaje wykrzyczana. Można tu odczytywać zjawy jako echo myśli Wrześmiana. Pogłębianie tego odczytania wskaże na kolejną analogię rodem z mitologii greckiej, gdzie nimfa Echo traci swą cielesność z rozpaczy za Narcyzmem, który też - w pewnym sensie - odmawia jej swojego ciała.

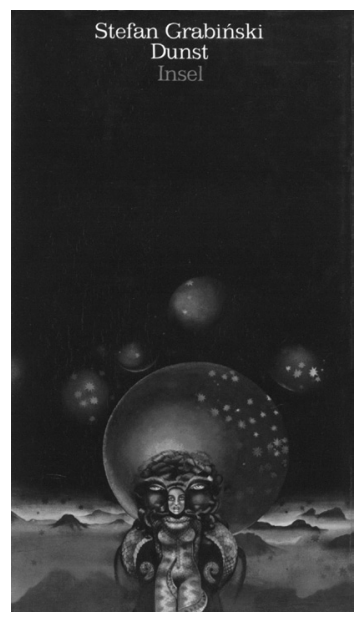

\section{S. Grabiński, Dunst und andere unheimliche Geschichten, Insel-Verlag,} Frankfurt am Main 1974 
miejsca i żyć w swobodzie!”, jest to właśnie żądanie nowych przestrzeni, których potencjał repetytywny nie został zużyty.

Zjawy Wrześmiana buntują się przeciwko swemu twórcy. Nie wystarczy im zaistnieć jako wyprojektowane myśli, chcą uzyskać wymiar w pełni cielesny, pragną biblijnej przemiany słowa w ciało. Zresztą scena agonii Wrześmiana także nawiązuje do Ewangelii. Ofiara z krwi i ciała zbliża bohatera do figury mesjańskiej. Nawet postawa, w jakiej umiera, z szeroko rozstawionymi rękoma, kojarzy się z krzyżową śmiercią Chrystusa. W chwili agonii następuje osiągnięcie pragnienia: wytwory Wrześmiana uzyskają cielesność. Jest to także pełnia jego wypowiedzenia. $\mathrm{W}$ ten sposób spotyka się ze sobą: komunikacja i komunia, wyrażenie i wspólnota. Eucharystia, będąca uobecnieniem nieobecnego, pozwala zaistnieć zjawom. Łukasz Majewski, wskazując na tożsamość hostii z mlekiem matki, interpretuje jej rytualne przyjmowanie w trakcie mszy świętej jako „lacanizującą wizję rite de passage”"3, czyli przejścia na „drugą stronę lustra”, która jest domeną znaku. Ofiara Wrześmiana stałaby się pomostem umożliwiającym przejście jego utworów z porządku imaginatywnego w porządek symboliczny. Ceną, jaką musi za to zapłacić, jest wycofanie się do porządku realnego.

Wrześmian umiera, ale jest to raczej śmierć jego tożsamości. W nowelach Grabińskiego rzadko bohater zostaje w pełni unicestwiony. W świecie niesamowitych opowieści śmierć nie jest końcem egzystencji, a zaledwie jego transformacją. Ingerencja świata nierealnego staje się jakby katalizatorem owych przeobrażeń. Niszczy stare struktury, które zostają zastąpione jakościowo nową formą istnienia.

Bohater Dziedziny nie jest tu wyjątkiem. Zaraz po jego śmierci powstaje nowy byt - potwór będący zlepkiem pokawałkowanego ciała, charakterystyczny dla Ja sprzed fazy lustra, kiedy to dziecko nie posiada jeszcze pełnej kontroli nad poszczególnymi częściami swojego ciała. Pokraczność ta manifestuje się nie tylko w sposobie poruszania się „krokiem chwiejnym, rozkołysanym", ale także w opisie wyglądu stwora, gdzie akcentowana jest odrębność poszczególnych części (ręki, tułowia, warg, nóg), a pominięte zostaje przedstawienie w sposób całościowy, jako jedna sylwetka (N, s. 289).

Dezintegracja ciała symbolizować może dezintegrację osobowości Wrześmiana, rozpad jego Ego wynikający z wycofania się z porządku symbolicznego. Porządek realny, w który owo wycofanie nastąpiło, jest w swej istocie traumatyczny, jego „przeblyski” w porządku symbolicznym jawią się właśnie jako elementy potworne, groźne zniekształcenia uporządkowanej rzeczywistości.

Przemiana ta jest ostatnim stadium regresji Wrześmiana. Początkowo wycofał się ze społeczeństwa, następnie zrezygnował z mowy, wreszcie wycofuje się z samego siebie, to jest z własnego Ego oraz z własnego ciała ${ }^{74}$. Inaczej ujmując: bohater ucieka z porządku symbolicznego w porządek wyobrażeniowy, a stamtąd w porządek realny. Jego potworna inkarnacja symbolizuje „niezorganizowany jeszcze $\mathrm{i}$ «zagubiony» w swych cielesnych odczuciach podmiot, odróżniane od Ego Ja, które nie wyszło jeszcze z porządku Realnego

73 Ł. Majewski, Ekstatyczna autokastracja. Psychoanalityczno-mitoznawcze ujęcie roli narcyzmu, zazdrości, żałoby i nekrofilii w kulcie Wielkiej Bogini Matki, Szczecin 2008, s. 116.

${ }^{74}$ W ten sposób wskazuje on na performatywny charakter tożsamości, cielesności. Każde wycofanie się motywowane jest tym, że element porzucany nie pochodzi od Wrześmiana, lecz zostaje mu zewnętrznie narzucony. 
w relację stawiającą je w sytuacji «niezgody z własną rzeczywistością»"75. Jeżeli Ego jest zawsze uwikłane w relację niezgody, to regres do Ja sprzed usymbolizowania będzie pogodzeniem się z rzeczywistością. W tym ujęciu symbol zawsze jest źródłem niezgody, co wynika z jego różności względem podmiotu.

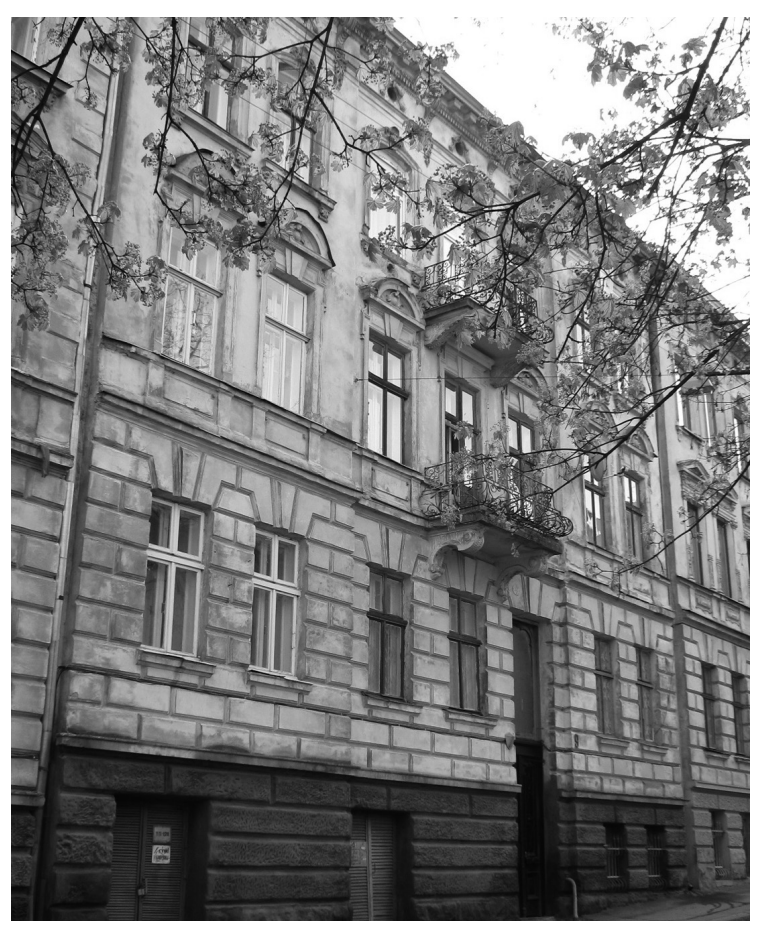

Dawna ul. Wronowskich we Lwowie, gdzie pisarz mieszkał przejściowo.

Fot. Tomasz Pudłocki, $2010 \mathrm{r}$.

Tożsamość katoptryczna dąży do reintegracji. Odbywa się ona często poprzez śmierć i odrodzenie w nowej postaci. Tak było w wypadku Stachura i profesora Czelawy. W Dziedzinie również katoptryczne projekcje bohatera dążą do ponownej integracji poprzez uśmiercenie stwórcy, który wreszcie odradza się jako ślad porządku realnego. Nie wiemy nic o dalszym losie zjaw i niewiedza ta jest tak natarczywa, że musi być znacząca. Skoro na skutek wycofania się Wrześmiana uzyskały one byt w wymiarze symbolicznym, to przemilczenie konotuje ich śmierć. W takiej sytuacji centralną postacią pozostałby Wrześmian. Ostateczny regres, porzucenie porządku symbolicznego oraz wyobrażeniowego kładzie jednocześnie kres egzystencjom wydobytym z jego imaginacji.

W Dziedzinie ponowne zintegrowanie się podmiotu nie następuje, ponieważ tożsamość zostaje zniesiona. Można to jednak odczytać jako prawdziwe i głębokie odzyskanie jedności poprzez odrzucenie różnicującego symbolu. Podmiot nieusymbolizowany traci tożsamość, lecz jednocześnie wyzbywa się rozdźwięku pomiędzy nią a Ja.

W ten sposób Dziedzina staje się opowiadaniem postmodernistycznym, a przynajmniej opowiadaniem o postmodernistycznej wymowie. Następuje w nim przeniesienie zainteresowania z modernistycznej fascynacji nieświadomymi elementami psychiki przejmującymi

\footnotetext{
75 Ł. Majewski, op. cit., s. 82.
} 
kontrolę nad poczynaniami jednostki (o czym traktowała wcześniej omówiona nowela) na postmodernistyczne zainteresowanie specyficznym rozwarstwieniem tożsamości i jej (ich) zakotwiczeniem poza podmiotem. Dziedzina jest więc krokiem naprzód, względem nie tylko wcześniejszej (a w dużej mierze także i późniejszej) twórczości Stefana Grabińskiego, ale całej literatury polskiej początku XX stulecia.

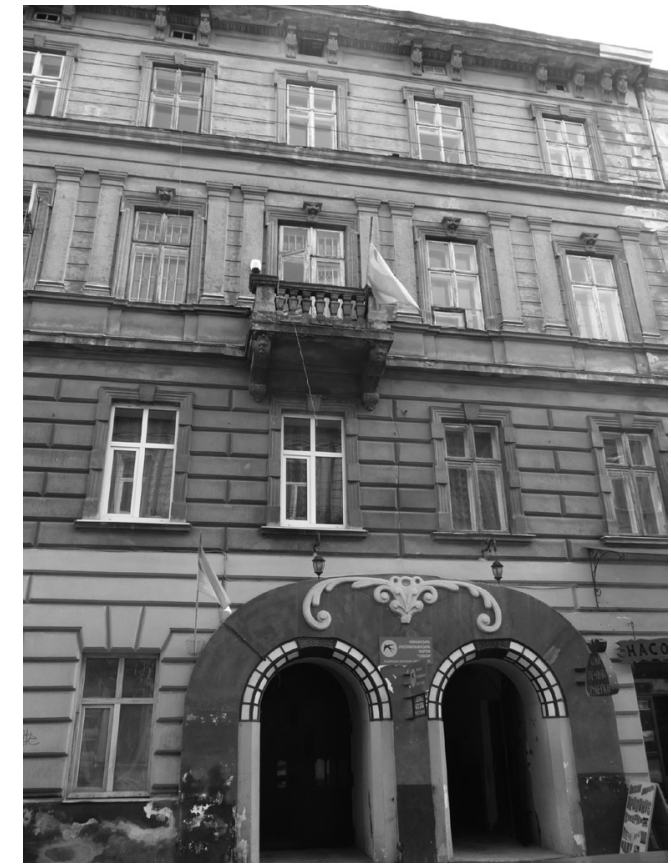

Dawna ul. Ossolińskich 10 we Lwowie, dokąd rodzina przeniosła się po śmierci ojca pisarza.

Fot. Tomasz Pudłocki, $2010 \mathrm{r}$.

Dla nas najciekawszy będzie fakt, że ów przeskok dokonał się za sprawą literackiej analizy tożsamości o charakterze katoptrycznym. Odbicie jest stanem zawieszenia między pełną obecnością a jej zupełnym brakiem. Podmiot staje przed lustrem i zarazem przed wyborem pomiędzy ustanowieniem siebie jako symbolu lub wpisaniem się $\mathrm{w}$ sferę imaginatywną jako coś tylko pomyślanego. Innymi słowy: wybrać musi, po której stronie lustra się znajduje. W 1959 roku Hutnikiewicz stwierdził:

Grabiński byl, jest i pozostanie na zawsze pisarzem wąskich, ekskluzywnych środowisk, w których na przekór powszechnej modzie i upodobaniom pielęgnuje się w ukryciu kult sztuki niezwykłej, ezoterycznych wtajemniczeń, marzeń, nieprzydatnych nikomu, w których się pieczołowicie ochrania egzotyczne, wielobarwne kwiaty fantastycznych urojeń [TLSG, s. 336].

W 21 lat później, przy okazji publikacji przez Wydawnictwo Literackie trzytomowych Utworów wybranych Grabińskiego, ten sam badacz pisał w zakończeniu przedmowy:

Grabiński wkracza, choć z wolna, ale pewnie na pole konkurencji światowej, wszedł już w poczet reprezentantów klasycznych romansu grozy w słynnej niemieckiej „Bibliotece Domu Usherów” [... ], odwołującej się w tytule do niesamowitego opowiadania Edgara Poego. Są więc podstawy 


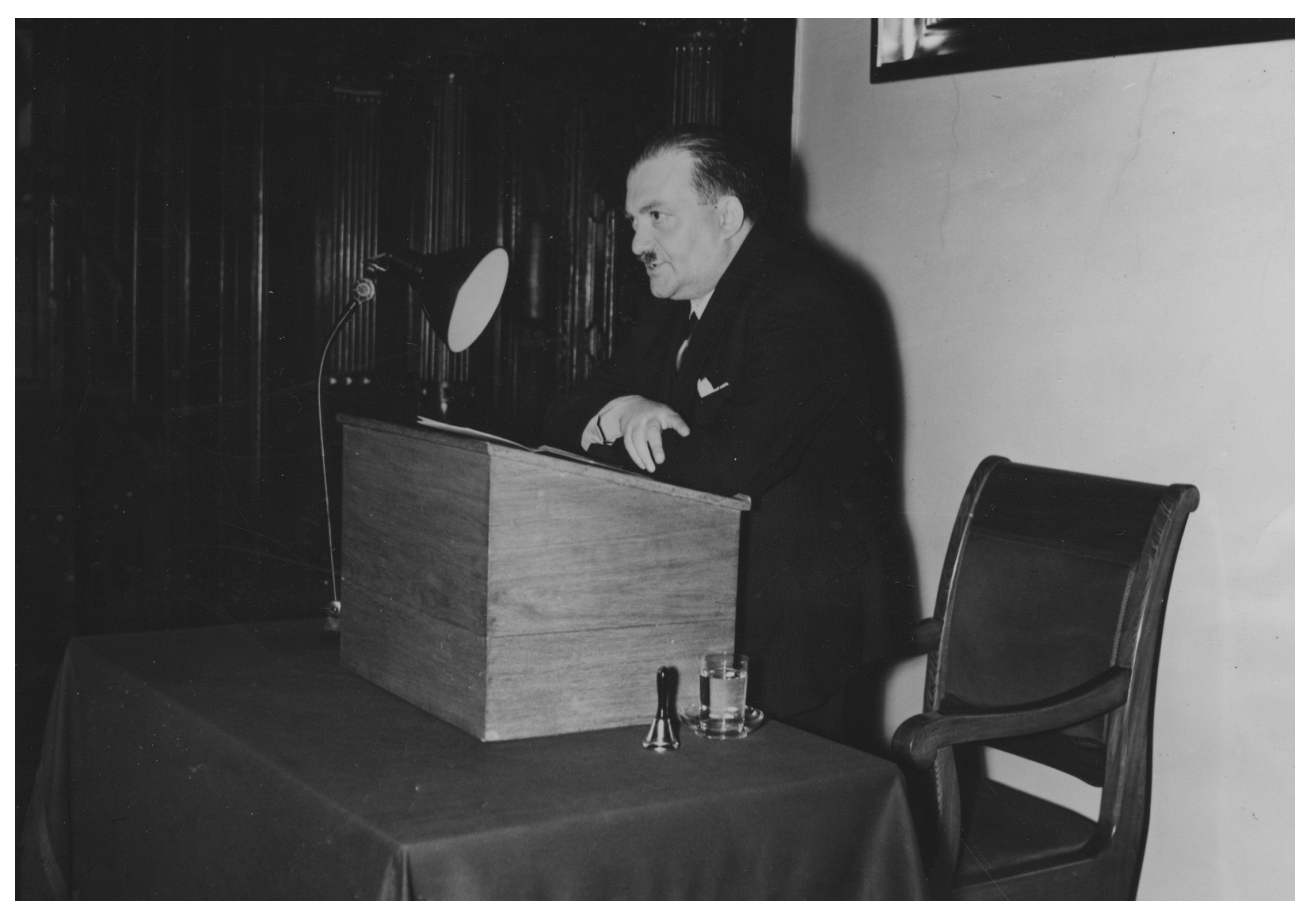

Kazimierz (zachowski

(1890-1948), bliski kolega

Grabińskiego, autor licznych recenzji jego utworów.

Ze zbiorów Narodowego

Archiwum Cyfrowego

do przypuszczeń, że będzie on przyciągał coraz silniej uwagę również czytelnika polskiego jako osobowość niezwykła. Polski Faust, przedziwnym trafem zabłąkany w nasze trzeźwe stulecie i na przekór wszystkim rozsądkom naszej podejrzliwej i sceptycznej epoki spisujący swoją fantastyczną opowieść o niesamowitej dziwności życia $[\mathrm{DO}, \mathrm{s.} 22]^{76}$.

Grabiński widziany na pierwszy z przywołanych sposobów jest możliwy wtedy, gdy rzeczywiście będziemy chcieli odczytywać jego utwory jako zapis „ezoterycznych wtajemniczeń", będących udziałem wąskiego grona. Reinterpretacja jego twórczości w proponowanym przeze mnie duchu psychoanalitycznym wraz z postulowanym powrotem do fantastyki nadaje tym nowelom charakter o wiele bardziej uniwersalny, pozwala dotrzeć do czytelników spoza tajemnych kręgów, jak i spoza początków XX wieku.

76 Poza wymienionym przez Hutnikiewicza tłumaczeniem Charlotte Eckert i Kurta Kelma (1953), anglojęzyczne zbiory nowel Grabińskiego ukazały się w przekładzie Mirosława Lipińskiego (The Dark Domain, 1993; The Motion Demon, 2005) i Wieśka Powagi (In Sarah's House, 2007). Ten ostatni zamieścił także dwa opowiadania Grabińskiego w opracowanym i przetłumaczonym przez siebie zbiorze The Dedalus Book of Polish Fantasy (1996). Na język portugalski Demona ruchu przełożył Wojciech Charchalis (O Demonio do Movimento, 2003). Na podstawie nowel Grabińskiego powstało do tej pory osiem adaptacji filmowych. Pierwsza, w reżyserii Leona Trystana, pochodzi już z roku 1927 (Kochanka Szamoty), najnowsze - z 1999 (Szamotas Geliebte) i z 2001 (Ultima Thule) - to niemieckie produkcje reżysera Holgera Mandla. 